\title{
THE
}

\section{Terrigenous Fe input and biogenic sedimentation in the glacial and interglacial equatorial Pacific Ocean}

\author{
R. W. Murray \\ M. Leinen \\ University of Rhode Island \\ D. W. Murray
}

A. C. Mix

Christopher W. Knowlton

University of Rhode Island, cknowlton@uri.edu

Follow this and additional works at: https://digitalcommons.uri.edu/gsofacpubs

Terms of Use

All rights reserved under copyright.

\section{Citation/Publisher Attribution}

Murray, R. W., M. Leinen, D. W. Murray, A. C. Mix, and C. W. Knowlton (1995), Terrigenous Fe input and biogenic sedimentation in the glacial and interglacial equatorial Pacific Ocean, Global Biogeochem. Cycles, 9(4), 667-684, doi: 10.1029/95GB02833.

Available at: https://doi.org/10.1029/95GB02833

This Article is brought to you for free and open access by the Graduate School of Oceanography at DigitalCommons@URI. It has been accepted for inclusion in Graduate School of Oceanography Faculty Publications by an authorized administrator of DigitalCommons@URI. For more information, please contact digitalcommons-group@uri.edu. 


\title{
Terrigenous Fe input and biogenic sedimentation in the glacial and interglacial equatorial Pacific Ocean
}

\author{
R. W. Murray, ${ }^{1}$ M. Leinen, ${ }^{2}$ D. W. Murray, ${ }^{3}$ A. C. Mix, ${ }^{4}$, and C. W. Knowlton ${ }^{2}$
}

\begin{abstract}
Many ocean regions important to the global carbon budget, including the equatorial Pacific Ocean, have low chlorophyll concentrations despite high levels of conventional nutrients. Iron may instead be the limiting nutrient, and elevated input of terrigenous $\mathrm{Fe}$ during windy glacial episodes has been hypothesized to stimulate oceanic productivity through time and thus regulate the oceanic and atmospheric $\mathrm{CO}_{2}$ balance. To test whether particulate $\mathrm{Fe}$ input is related to the accumulation of biogenic matter in one important low chlorophyll-high nutrient area, that is, the equatorial Pacific Ocean, we present results from a suite of sediment cores that collectively record biogenic deposition through the last six glacial-interglacial cycles $(\sim 600,000$ years). Our data set includes new chemical data on total $\mathrm{Fe}$, terrigenous, and biogenic components in three cores as well as previously published mineralogic records of eolian input to the region. Chemical, spectral, and stratigraphic analysis indicates that (1) terrigenous input to the region shows no consistent pattern of either glacial or interglacial maxima, (2) the accumulation of particulate Fe is closely related to the accumulation of terrigenous matter (linear $\left.r^{2}=0.81-0.98\right)$, (3) there are no coherent spectral relationships between $\mathrm{Fe}$ input and glacial periodicity (i.e., $\delta^{18} \mathrm{O}$ ) in any of the orbital frequency bands, (4) the linear and cross-spectral correlations between $\mathrm{Fe}$ or eolian input and $\mathrm{CaCO}_{3}$ concentration are most commonly the strongest observed relationships between $\mathrm{Fe}$ and any biogenic component, yet indicate a largely inverse pattern, with higher Fe being associated with low $\mathrm{CaCO}_{3}$, (5) there is no consistent linear $r^{2}$ correlation or spectral coherence between the accumulation of $\mathrm{Fe}$ and that of $\mathrm{CaCO}_{3}, \mathrm{C}_{\text {org }}$, or opal. Thus in total there is no relationship between terrigenous Fe input and sedimentary sequestering of carbon. Additionally, although we cannot specifically address the potential for changes in solubility of the terrigenous fraction that may be driven by a terrigenous compositional change, the Fe/Ti ratio (which monitors first-order mineralogic changes) records only slight variations that also are linearly and spectrally unrelated to glacial periodicity, the bulk Fe flux, and the accumulation of any biogenic component. Finally, we find that the paleoceanographic flux of $\mathrm{Fe}$ is several order-of-magnitudes larger than modern observations of eolian $\mathrm{Fe}$ input, suggesting that the long-term importance of Fe input by dust storms (which deliver Fe on the order of the sedimentary burial) may be underestimated. The removal of particulate terrigenous $\mathrm{Fe}$ from the recently discovered source within the Equatorial Undercurrent, however, remains unquantified and may also prove significant.
\end{abstract}

\section{Introduction}

Three questions about the biogeochemical relationship between $\mathrm{Fe}$ and marine phytoplankton production have been highlighted for their potential importance to the oceanic and atmospheric $\mathrm{CO}_{2}$ balance:

1. Does Fe limit modern-day production in regions like the equatorial Pacific and Southern Ocean, where low chlorophyll

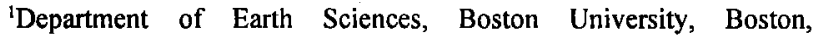
Massachusetts

${ }^{2}$ Graduate School of Oceanography, University of Rhode Island, Narragansett

${ }^{3}$ Department of Geological Sciences, Brown University, Providence, Rhode Isalnd

${ }^{4}$ College of Oceanic and Atmospheric Sciences, Oregon State University, Corvallis
}

Copyright 1995 by the American Geophysical Union.

Paper number $95 \mathrm{~GB} 02833$.

0886-6236/95/95GB-02833\$10.00 concentrations are associated with high levels of conventional nutrients $\left(\mathrm{NO}^{3-}, \mathrm{PO}_{4}{ }^{3-}, \mathrm{SiO}_{2}\right)[$ Martin et al., 1990, 1991; Barber and Chavez, 1991; Bruland et al., 1991; Morel et al., 1991; Price et al., 1991; Frost and Franzen, 1992; DiTullio et al., 1993; Kolber et al., 1994; Martin et al., 1994]?

2. Would Fe fertilization stimulate production and thus be an effective strategy to sequester atmospheric $\mathrm{CO}_{2}$ in sedimentary calcium carbonate $\left(\mathrm{CaCO}_{3}\right)$ and organic carbon $\left(\mathrm{C}_{\text {org }}\right)$ through sedimentary burial (and thus final removal from the oceanatmosphere system) [Martin et al., 1990; Peng and Broecker, 1991; Martin, 1992; Watson et al., 1994]? and

3. Did natural Fe fertilization via terrigenous input occur over glacial-interglacial timescales [e.g., Martin, 1990; Berger and Wefer, 1991]?

The equatorial Pacific plays an important role in the debate over Fe limitation of oceanic productivity because it has been specifically implicated in each of the three questions listed above and is critically important to global studies of ocean-atmosphere carbon cycling [e.g., Murray et al., 1994]. As such, although models predict the Fe-fertilized consumption of conventional nutrients in the Southern Ocean is more important to the 
atmospheric concentration of $\mathrm{CO}_{2}$ [Sarmiento and $\mathrm{Orr}, 1991$ ], the equatorial Pacific was the location of a recently concluded experiment in which a large oceanic area was artificially fertilized with $\mathrm{Fe}$ and the biologic response was monitored [Kolber et al., 1994; Martin et al., 1994; Watson et al., 1994]. Thus we focus on the equatorial Pacific Ocean to study the relationships between the input of terrigenous matter, total $\mathrm{Fe}$, and biogenic sedimentation through time.

In this paper, we test the hypothesis that long-term variation in terrigenous $\mathrm{Fe}$ flux has been associated with sequestering of carbon in the equatorial Pacific by examining the sedimentary record of the total $\mathrm{Fe}$ accumulation during the last six glacialinterglacial cycles $(600,000 \mathrm{yr}=600 \mathrm{kyr})$. We report new chemical data that result from the chemical measurement of total Fe in three cores in the vicinity of $130^{\circ}-140^{\circ} \mathrm{W}$, two of which (GC51 and PC72) record Fe input for the past $600 \mathrm{kyr}$ while the third (GC14) presents a shorter but higher resolution record (Figure 1; Table 1). We interpret these chemical data in the context of previously published mineralogic records of eolian input to the region, based on data from Core RC11-210 and Deep Sea Drilling Project (DSDP) Hole 503B (Table 1) [Rea et al., 1986; Chuey et al., 1987; Pisias and Rec, 1988; Rea et al., 1991]. Although DSDP 503B is located well to the east of the other four cores located in the central equatorial Pacific (Figure 1), and thus in a different carbonate regime [Snoeckx and Rea, 1994], it is a particularly well-studied core in terms of the biogenic and eolian components (Table 1), and so it is appropriate to consider here. As we discuss below, our results address the first-order issue of the biogenic response to the total $\mathrm{Fe}$ input to the system, not the amount of reactive Fe. We will also address, however, the glacial-interglacial timing and extent of potential variations in reactive $\mathrm{Fe}$ input, and provide quantitative constraints on such potential variation.

\section{Biogenic Production: The Sedimentary Record}

Considering the capability of the sedimentary paleochemical record to provide insight into the three biogeochemical questions

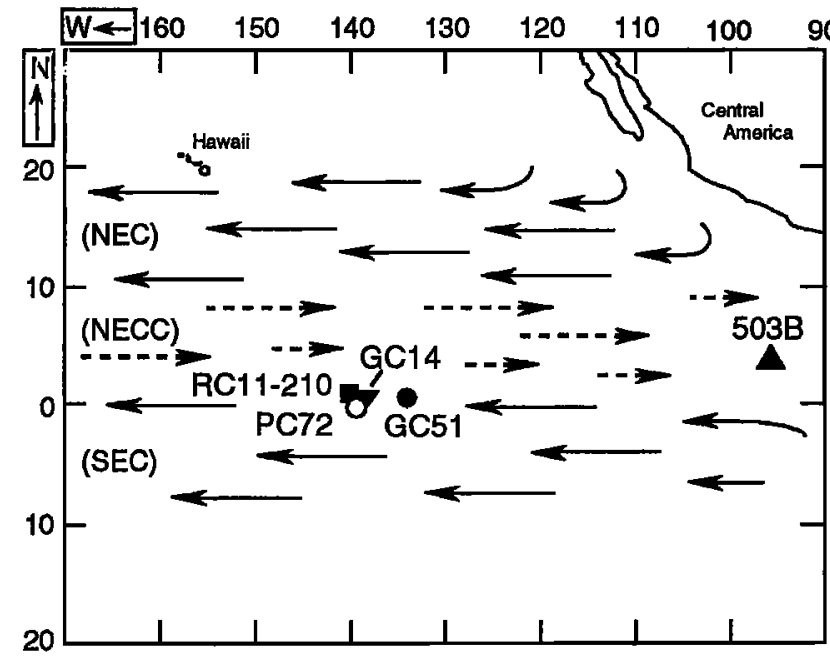

Figure 1. Map indicating locations of cores discussed in this study. See Table 1 for complete geographic information. Representative positions of surface ocean currents schematically shown as follows: NEC, North equatorial Current; NECC, North equatorial Countercurrent; SEC, South equatorial Current. highlighted above, there are several critical issues that first must be addressed. We are unable to address question 1 througb investigation of the paleochemical record because even the youngest sampled sediment in the region provides only a cumulative average signal of deposition over the past $\sim 500 \mathrm{yr}$ [e.g., Murray and Leinen, 1993; and references therein]. There is a rich literature that more appropriately addresses the topic of Fe limitation in the present-day equatorial Pacific (as cited above).

To investigate the second question quantitatively requires an understanding of the causes of the biogenic sedimentary cycles in the equatorial Pacific. The literature provides much discussion of whether Quaternary $\mathrm{CaCO}_{3}$ and $\mathrm{C}_{\text {org }}$ maxima throughout the equatorial Pacific predominantly reflect variations in productivity [e.g., Arrhenius, 1952; Pedersen, 1983; Lyle et al., 1988, 1992; Archer, 1991; Pedersen et al., 1988, 1991; Murray et al., 1993; Herguera and Berger, 1994] or dissolution intensity [e.g., Berger, 1973; Emerson, 1985; Farrell and Prell, 1991]. Indeed, although the debate is often posed in a mutually exclusive framework (i.e., production or dissolution), it is more appropriate to consider the linkage between the two processes: As synthesized by Berger [1992], it is the large-scale glacialinterglacial changes in productivity that may also be responsible for varying dissolution intensity. While it is beyond the scope of this paper to settle or debate this issue, we believe that the biogenic cycles we discuss predominantly reflect productivity variations. There are many lines of evidence to support this, including the broadly similar patterns of $\mathrm{CaCO}_{3}, \mathrm{C}_{\text {org }}$, and opal accumulation [e.g., Lyle et al., 1988; Rea et al., 1991] (each responding to different dissolution mechanisms; e.g., Martin et al., [1991]), modeling considerations [e.g., Archer, 1991], a variety of trace metal proxies such as $\mathrm{Ba}$, sedimentary $\mathrm{I}$, scavenged Al, and redox sensitive metals [e.g., Pederson, 1983; Pederson et al., 1988; Dymond et al., 1992; Murray et al., 1993; R. W. Murray and M. Leinen, unpublished data, 1995], faunal abundances [e.g., Pederson et al., 1988; Herguera and Berger, 1991], as well as others. Most importantly, recall that question 2 concerns the relationship between $F e$ input and sequestration of atmospheric $\mathrm{CO}_{2}$ through final sedimentary burial. Thus variations in dissolution that are superimposed upon the larger productivity signal [e.g., Wei et al., 1994] will not compromise the sedimentary paleochemical record's capability to accurately document temporal changes in final carbon sequestration and terrigenous $\mathrm{Fe}$ input.

Building on this discussion, the final question, which addresses the most important issue of this paper, will be addressed below by comparison of the terrigenous $\mathrm{Fe}$ input through time. By monitoring the input of terrigenous material, the input of $\mathrm{Fe}$, and the accumulation of the biogenic components, we will examine the relationship between the potential for Fe fertilization and the biogenic response.

\section{Sources of Eolian, Terrigenous, and Particulate Fe}

The Fe hypothesis of phytoplankton limitation in the equatorial Pacific was originally phrased in the context of the $\mathrm{Fe}$ being delivered via eolian input [e.g., Martin, 1990; Martin et al., 1994]. Recently, however, it was discovered that the Equatorial Undercurrent (EUC) carries a substantial dissolved and particulate load of $\mathrm{Fe}$ to the central equatorial Pacific, and that 
Table 1. Core Locations and Data Type

\begin{tabular}{|c|c|c|c|c|c|}
\hline Core & $\begin{array}{l}\text { Latitude, } \\
\text { deg North }\end{array}$ & $\begin{array}{l}\text { Longitude, } \\
\text { deg West }\end{array}$ & $\begin{array}{l}\text { Depth, } \\
\text { m }\end{array}$ & Data Type & Data Source \\
\hline WEC8803B-GC51 & 1.3 & 133.6 & 4410 & $\begin{array}{l}\mathrm{Fe}, \mathrm{Ti}, \mathrm{CaCO}_{3}, \\
\mathrm{C}_{\text {org }} \text { opal }\end{array}$ & $\begin{array}{l}\text { This work, and } \\
\text { Murray et al. } \text { [1993] }\end{array}$ \\
\hline WEC8402A-GC14 & 0.95 & 139 & 4287 & $\begin{array}{l}\mathrm{Fe}, \mathrm{Ti}, \mathrm{CaCO}_{3}, \\
\mathrm{C}_{\text {org }}, \text { opal }\end{array}$ & $\begin{array}{l}\text { This work, and } \\
\text { Murray [1987] }\end{array}$ \\
\hline TT013-PC72 & 0.1 & 139.4 & 4298 & $\mathrm{Fe}, \mathrm{Ti}, \mathrm{CaCO}_{3}$ & This work \\
\hline $\mathrm{RC} 11-210$ & 1.8 & 140 & 4420 & $\begin{array}{l}\text { Eolian, } \mathrm{CaCO}_{3} \text {, } \\
\mathrm{C}_{\text {org }} \text {, opal }\end{array}$ & $\begin{array}{l}\text { Chuey et al. }[1987] \\
\text { Pisias and Rea [1988] } \\
\text { Rea et al. }[1991]\end{array}$ \\
\hline DSDP 503B & 4.0 & 95.6 & 3672 & $\begin{array}{l}\text { Eolian, } \mathrm{CaCO}_{3} \text {, } \\
\mathrm{C}_{\text {org }} \text {, opal }\end{array}$ & Rea et al. [1986] \\
\hline
\end{tabular}

this EUC input is a far more significant source to the euphotic zone than eolian input [Gordon et al., 1995]. Chemical analyses of this EUC particulate matter suggest that it is similar in composition to upper continental crust [Gordon et al., 1995], and thus at this point we cannot distinguish in the sediment between particulate matter advected in the EUC and eolian particulate matter. Because of this, we refer to the total $\mathrm{Fe}$ in the sediment in the cores which we chemically analyzed as "terrigenous" (i.e., indistinguishable between advected and eolian sources). For RC11-210 and DSDP 503, however, the operationally defined eolian fraction was analyzed by previous workers (discussed below), and we indeed refer to this fraction as "eolian". The Fe analyses measure variation in the amount of total $\mathrm{Fe}$ supplied to the system via the combined sources of eolian input and the EUC, and we are thus examining in the sedimentary record the Fe fertilization hypothesis in the context of the relationship between the total $\mathrm{Fe}$ input and biogenic sedimentary response.

\section{Analytical Methodology and Stratigraphy}

Complete core and geographic information is provided in Table 1, as is a summary of the available data discussed in this paper. Calcium carbonate in gravity core WEC8803B-GC51 (subsequently abbreviated as "GC51") and piston core TT013PC72 (abbreviated as "PC72") was determined by standard coulometric techniques, as was $\mathrm{C}_{\text {org }}$ in GC51 (see Murray et al. [1993] for determinations of precision and accuracy). Opal in GC51 was determined using a normative calculation that was calibrated to opal measured by a timed-dissolution technique on similar samples from the equatorial region [Murray and Leinen, 1993]. Biogenic components in WEC8402A-GC14 (abbreviated as "GC14") were determined as described in Murray [1987]. Data for the biogenic components in RC11-210 and DSDP 503B (abbreviated as "503B") were taken from the literature [Rea et al., 1986; Chuey et al., 1987; Pisias and Rea, 1988; Rea et al., 1991].

For GC51, total Fe and Ti were determined by Xray fluorescence spectrometry (XRF) (XRay Assay Laboratories, Toronto, Canada); precision, determined by blind analysis of $\sim$
10 replicate powders submitted over three different analytical runs several months apart, is $7 \%$ of the measured value for $\mathrm{Fe}$ and $2 \%$ of the measured value for Ti. Accuracy was assessed by blind analysis of reference sediment NBS-1C (argillaceous limestone, $\mathrm{Fe}=0.38 \mathrm{wt}$. \%; $\mathrm{Ti}=0.04 \mathrm{wt}$. \%); values agree within precision. To verify Fe data in GC51, 21 samples selected to represent the entire $\mathrm{Fe}$ concentration range were also analyzed by inductively coupled plasma-emission spectrometry (ICP-ES) at Boston University, using sample preparation methods described by Murray and Leinen [1993]. Agreement between XRF and ICP-ES data was excellent even for the lowest Fe concentrations, and because the ICP-ES data are preferred for reasons of quality control the original XRF data were slightly corrected by a linear regression generated from the comparative data $\left(r^{2}=0.984\right)$. These corrections do not affect the temporal pattern of $\mathrm{Fe}$ abundance or accumulation in any way, and the dual measurements serve to verify and confirm the analytical results. Owing to the extremely high $\mathrm{CaCO}_{3}$ concentrations in some samples (up to $91 \mathrm{wt}$ \%), some Ti values are below the XRF detection limit. For PC72, Fe and Ti were determined by ICP-ES at Boston University. Precision was assessed by repeated preparation and analysis of sediment from the $432-$ to $433-\mathrm{cm}$ interval of PC72, and is $4 \%$ of the measured value for both $\mathrm{Fe}$ and Ti. Accuracy was assessed by analysis of reference sediment NBS-1C (described above), values agree within precision. Because the amounts of $\mathrm{Fe}$ and $\mathrm{Ti}$ in NBS-1C are somewhat greater than are found in equatorial Pacific samples, however, we also analyzed an aliquot of NBS-1C that had been diluted as a powder by ultrapure $\mathrm{CaCO}_{3}$ powder (ULTREX, J. T. Baker, Inc.) to $\mathrm{Fe}$ and $\mathrm{Ti}$ concentrations ( $\mathrm{Fe} \sim 300 \mathrm{ppm}, \mathrm{Ti} \sim 30 \mathrm{ppm}$ ) more representative of or lower than those found naturally. The analyzed concentrations of both $\mathrm{Fe}$ and $\mathrm{Ti}$ in this modified reference, as well as the $\mathrm{Fe} / \mathrm{Ti}$ ratio, also agreed within precision to the expected values. For GC14, Fe and Ti were determined using a wavelength dispersive Philips PW1600 simultaneous XRF spectrometer at Oregon State University [Murray, 1987]. Values presented here have been slightly adjusted from the original data in Murray [1987], based on comparative atomic absorption spectrometry (AA) analyses of a suite of samples from GC14 and a nearby box core. Although the trends are similar, 
XRF values were subsequently linearly corrected to the preferred AA results; again, these corrections do not affect the temporal pattern of Fe abundance or accumulation in any way and the dual measurements serve to verify and confirm the analytical results. Precision of the GC14 analyses remains better than $3 \%$ and accuracy is better than $7 \%$ of the measured value.

The age model for GC51 ties together the $\delta^{18} \mathrm{O}$-based age model using Globorotalia tumida from 0 to $412 \mathrm{kyr}$ [LaMontagne, 1993] and the carbonate-based age model from 412 to $619 \mathrm{kyr}$ [Murray et al., 1993] that is based on correlation of $\mathrm{CaCO}_{3}$ concentration in GC51 to that in RC11-210 which is in turn isotopically calibrated to the SPECMAP stack [Pisias and Rea 1988]. The age model for GC14 is based on a correlation to the SPECMAP stack [Imbrie et al., 1984] of the $\delta^{18} \mathrm{O}$ record measured on $G$. tumida using the signal correlation technique of Martinson et al. [1982] and eight coefficients to define the mapping function. Accumulation rates for GC14 presented here are slightly different from those presented graphically by Lyle et al. [1988], due to small revisions of the age model. The age model for PC72 was determined by $\delta^{18} \mathrm{O}$ analysis of Cibicides wuellerstorfi and correlation to the SPECMAP stack [Imbrie et al., 1984]. The age models for RC11-210 and 503B are taken from the literature [Rea et al.,.1986; Pisias and Rea, 1988]. Only the 0 to $600 \mathrm{kyr}$ portion of the published record from RC11-210 is reproduced here because it is only this interval that we can compare to the 0 to $600 \mathrm{kyr}$ records of GC51 and PC72. As will be shown below, slight differences in the age models between the various cores discussed here will not affect the main points of this paper. We instead emphasize variations within each core and further note that these variations are internally consistent between the cores.

Accumulation rates were calculated using the standard protocol of the accumulation rate of a given element (or component) equaling the product of linear sedimentation rate (derived from the age model), dry bulk density, and concentration of the element or component in question. For GC51 and PC72, dry bulk density was calculated from a relationship between $\mathrm{CaCO}_{3}$ and dry bulk density specific to this region [Murray and Leinen, 1993]. For GC14, dry bulk density was determined using methods described by Murray [1987]. The accumulation of the biogenic and eolian components in RC11-210 and 503B are taken from Rea et al. [1986], Chuey et al. [1987], and Pisias and Rea [1988], in which the operationally defined eolian component was determined by a series of chemical extractions. Eolian accumulation rates in $\mathrm{RC11-210}$ for samples younger than $50 \mathrm{kyr}$ are not presented because they are referred to by the original authors as "anomalous"; there also is an ash layer at $75 \mathrm{kyr}$ [Chuey et al., 1987]. In 503B, the eolian and opal accumulation rates were measured on slightly different intervals than were the accumulations of $\mathrm{CaCO}_{3}$ and $\mathrm{C}_{\text {org }}$. For purposes of calculating correlation coefficients (see below), the accumulations of eolian and opal were linearly interpolated onto the depths for which $\mathrm{CaCO}_{3}$ and $\mathrm{C}_{\text {org }}$ were measured.

Spectral analyses of the cores for which we have chemical data was performed using standard menu-driven software from Brown University that is based on the Blackman-Tukey method [Jenkins and Watts, 1968]. For GC51, spectral analyses were performed only on the portion of the core with ages that are isotopically defined ( 0 to $412 \mathrm{kyr}$ ). Interpretation of the $100 \mathrm{kyr}$ period in GC14 (a $240 \mathrm{kyr}$ record) must be made with caution because only two $100 \mathrm{kyr}$ cycles are recorded.

\section{Results}

Data for GC51, GC14, and PC72 are given in the appendices (Tables A1 - A3). Linear correlation coefficients $\left(r^{2}\right)$ between the accumulation of the biogenic components, the accumulation of the respective eolian component, the $\mathrm{Fe} / \mathrm{Ti}$ ratio $(\mathrm{g} / \mathrm{g})$, and the concentration of $\mathrm{CaCO}_{3}$ (wt. \%) are given in Table 2. Results of cross-spectral analyses are given in Table 3. Downcore profiles of the various components for each core are presented in Figures 2 - 6. The concentration of $\mathrm{CaCO}_{3}$ is plotted only for the cores for which the new Fe data is given (GC51, GC14, and PC72); similarly, spectral analyses were only performed on these cores.

Downcore profiles of $\mathrm{CaCO}_{3}$ concentration and accumulation in all cores display the well-known increases and decreases that broadly follow glacial-interglacial cyclicity (as cited above). In GC51, GC14, and PC72, the accumulation of Ti, which we use to track terrigenous input [Taylor and McLennan, 1985; Murray et al., 1993], records maxima during both glacial and interglacial periods, with no consistent pattern. In all cores, the accumulation of Fe closely follows that of the terrigenous component, as measured by $\mathrm{Ti}$ (Tables 2 and 3). Most significantly, in these cores the accumulation of $\mathrm{Fe}$ is not related to the accumulation of $\mathrm{CaCO}_{3}, \mathrm{C}_{\text {org }}$, or opal, neither in terms of the linear $r^{2}$ values (Table 2) nor in terms of spectral coherence (Table 3). In four of the five cores, the strongest linear $r^{2}$ correlation between $\mathrm{Fe}$ or terrigenous accumulation and any biogenic variable is with $\mathrm{CaCO}_{3} \mathrm{wt}$ \% , and this correlation is negative. (The relatively strong $r^{2}$ between Fe and opal accumulation in GC51 results essentially solely from the paired maximum at $~ 330 \mathrm{kyr}$.) In the one core for which the correlation is not negative (RC11-210), the correlation between eolian input and $\mathrm{CaCO}_{3}$ wt. \% is exactly zero and the correlation between eolian input and the accumulation of $\mathrm{CaCO}_{3}, \mathrm{C}_{\text {org }}$, and opal also are essentially zero (respectively, 0.01, 0.02, and 0.04; Table 2). Spectral analyses confirm the lack of consistent relationship between the accumulation of $\mathrm{Fe}$ and the accumulation of any biogenic component at any orbital frequency, as well as the much stronger and essentially inversely related $\left(\sim 180^{\circ}\right.$ out-of-phase) relationship between $\mathrm{Fe}$ accumulation and $\mathrm{CaCO}_{3}$ abundance (Table 3).

In GC51 and PC72, the Fe/Ti ratio records a long-term decrease from $600 \mathrm{kyr}$ to $\sim 350 \mathrm{kyr}$, after which it either slightly increases or maintains a relatively constant median value to modern-day levels (Figures 2 and 4). There are also higher frequency variations superimposed on these long-term trends, such as found in GC14 (Figure 3). Neither the long-term trend nor the short-term variability in $\mathrm{Fe} / \mathrm{Ti}$ is related to glacial periodicity, nor are they significantly related to the accumulation of any biogenic component (Tables 2 and 3 ).

In RC11-210, the accumulation of the eolian component records both glacial and interglacial maxima (Figure 5). In 503B, eolian accumulation appears to be predominantly interglacial (Figure 6). In both cores, eolian accumulation is unrelated to the accumulation of any of the biogenic components.

\section{Discussion}

For the following reasons, we interpret the Fe profiles in GC51, GC14, and PC72 as records of the terrigenous input of Fe 
Table 2. Linear Corrclation Coefficients Between Fe, Ti, and Biogenic Accumulation, as well as $\mathrm{Fe} / \mathrm{Ti}$ and $\mathrm{CaCO}_{3}$ Abundance

\begin{tabular}{lllllllll}
\hline $\mathrm{Fe}$ & $\mathrm{Ti}$ & $\mathrm{CaCO}_{3}$ & $\mathrm{C}_{\text {org }}$ & Opal & $\mathrm{Fe} / \mathrm{Ti}$ & $\mathrm{CaCO}_{3}, \%$ & Eolian \\
\hline
\end{tabular}

$\begin{array}{lr}\mathrm{Fe} & 1.00 \\ \mathrm{Ti} & 0.93 \\ \mathrm{CaCO}_{3} & 0.09 \\ \mathrm{C}_{\text {org }} & 0.1 \\ \mathrm{Opa} & 0.5 \\ \mathrm{Fe} / \mathrm{Ti} & -0.08 \\ \mathrm{CaCO}_{3}(\%) & -0.1\end{array}$

$\begin{array}{lr}1.00 & \\ 0.93 & 1.00 \\ 0.09 & 0.05 \\ 0.16 & 0.14 \\ 0.53 & 0.50 \\ 0.08 & -0.20 \\ 0.17 & -0.24\end{array}$

GC51 $(0-600 \mathrm{kyr})$

\begin{tabular}{lrrrr}
1.00 & & & & \\
0.24 & 1.00 & & & \\
0.46 & 0.41 & 1.00 & & \\
0.00 & -0.03 & -0.06 & 1.00 & \\
0.30 & 0.00 & 0.00 & 0.26 & 1.00 \\
\multicolumn{4}{l}{ GC14 (0-240 kyr) }
\end{tabular}

$\begin{array}{lr}\mathrm{Fe} & 1.00 \\ \mathrm{Ti} & 0.8 \\ \mathrm{CaCO}_{3} & -0.0 \\ \mathrm{C}_{\text {org }} & 0.00 \\ \mathrm{Opa1} & -0.07 \\ \mathrm{Fe} / \mathrm{Ti} & 0.23 \\ \mathrm{CaCO}_{3}(\%) & -0.1\end{array}$

1.00
0.81
0.01
0.00
0.07
0.23
0.11

1.00
0.04
0.03
-0.01
0.00
0.00

\begin{tabular}{rrrr}
1.00 & & & \\
0.48 & 1.00 & & \\
0.04 & 0.18 & 1.00 & \\
-0.27 & -0.17 & -0.14 & 1.00 \\
0.73 & 0.30 & 0.00 & -0.26 \\
\multicolumn{4}{c}{$P C 72(0-600$ kyr $)$}
\end{tabular}

\begin{tabular}{|c|}
\hline $\begin{array}{l}\mathrm{Fe} \\
\mathrm{Ti} \\
\mathrm{CaCO} \\
\mathrm{Fe} / \mathrm{Ti}_{3} \\
\mathrm{CaCO}_{3}(\%)\end{array}$ \\
\hline
\end{tabular}

1.00
0.97
0.01
0.05
0.46

1.00
-0.03
-0.15
-0.52

1.00
0.12
0.35

0.16

1.00

RC11-210 (0 - 600 kyr)

Eolian
$\mathrm{CaCO}_{3}$
$\mathrm{C}_{\text {org }}$
Opal
$\mathrm{CaCO}_{3}(\%)$

1.00

1.00
0.54
0.05

0.05
0.55

1.00

0.05

0.20

1.00
-0.03

DSDP 503B (0 - 420 kyr)

Eolian
$\mathrm{CaCO}_{3}$
$\mathrm{C}_{\text {org }}$
Opa
$\mathrm{CaCO}_{3}(\%)$

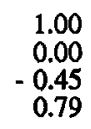

1.00
0.00
-0.45
0.79

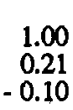

$\begin{array}{rr}1.00 & 1.00 \\ 0.21 & -0.72\end{array}$

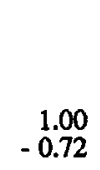

.00

Linear correlation coefficients are $r^{2}$. Missing values are for data not gathered for that particular core. $\mathrm{CaCO}_{3} \%$ is $\mathrm{CaCO}_{3}$ abundance.

to the central equatorial Pacific: (1) This region is not affected by the largescale hydrothermal inputs that are located well to the east [Leinen and Stakes, 1979; Dymond, 1981; Murray and Leinen, 1993]; (2) although the Fe/Ti ratios in these cores (ranging from $~ 10$ to 25 ) are often somewhat greater than that of average pelagic clay $(=14)$ [Taylor and McLennan, 1985] and Mesozoic/Cenozoic andesite $(=11)$ [Condie, 1993] (and thus could be interpreted as reflecting variation in the abundance of diagenetic oxides), iron oxides, however, are themselves known to be common components of colian dust [Duce and Tindale, 1991; and references therein]; (3) the fact that the $\mathrm{Fe}$ and $\mathrm{Ti}$ accumulation profiles record identical downcore patterns in each of the three cores indicates that the $\mathrm{Fe}$ and $\mathrm{Ti}$ share a primary and common terrigenous source; and (4) Fe accumulation varies by up to a factor of 4, which is greater than can be explained by the maximum potential variation (between 30 and $45 \%$; Murray [1987]) in the diagenetic and eolian oxide component, indicating that oxides are not the primary Fe-bearing phase in these sediments. Thus we conclude that our measurements of total $\mathrm{Fe}$ reflects terrigenous $\mathrm{Fe}$ in these sediments.

\section{Glacial and Interglacial Input of Fe}

The temporal patterns of $\mathrm{Fe}$ input in these cores do not support the hypothesis that long-term variation in total $\mathrm{Fe}$ input controls glacial-interglacial biogenic cyclicity [Martin, 1990; Berger and Wefer, 1991]. First, the terrigenous and eolian accumulation patterns (based on Ti in GC14, GC51, and PC72, and the eolian measurements in $\mathrm{RC} 11-210$ and 503B) show no consistent increase during glacial episodes. Second, linear and spectral analysis show that there is no evidence that $\mathrm{CaCO}_{3}, \mathrm{C}_{\text {org }}$, or opal accumulation was related to the flux of Fe during the past six glacial-interglacial cycles. Third, the linear $r^{2}$ and spectral correlations between $\mathrm{Fe}$ or eolian input and $\mathrm{CaCO}_{3}$ concentration is either negative or zero (for the $r^{2}$ ) or essentially $180^{\circ}$ out-ofphase (for the cross-spectral analysis, and only where there is any relationship at all). Thus there is no evidence that the input of Fe influenced the final sedimentary sequestering of biogenically produced carbon in the equatorial Pacific.

Comparing these chemical records to the mineralogic studies of eolian accumulation in RC11-210 and 503B confirms the lack 
Table 3. Results of Cross-Spectral Analysis, Cores GC14, GC51, PC72

\begin{tabular}{|c|c|c|c|c|c|}
\hline \multirow[b]{2}{*}{ Variables } & \multirow[b]{2}{*}{ Core } & \multicolumn{4}{|c|}{ Phase Difference \pm Phase Error / Coherency 2} \\
\hline & & & $100 \mathrm{kyr}$ & $41 \mathrm{kyr}$ & 23 kyr \\
\hline Fe acc. $/ \delta^{18} \mathrm{O}$ & $\begin{array}{l}\text { GC14 } \\
\text { GC51 } \\
\text { PC72 }\end{array}$ & $\begin{array}{r}-261 \\
92\end{array}$ & $\begin{array}{l} \pm 12 / 0.84 \\
\pm 10 / 0.81\end{array}$ & $97 \pm 20 / 0.60$ & \\
\hline Fe acc. / Carb. \% & $\begin{array}{l}\text { GC14 } \\
\text { GC51 } \\
\text { PC72 }\end{array}$ & $\begin{array}{l}131 \\
160\end{array}$ & $\begin{array}{l} \pm 14 / 0.81 \\
\pm 12 / 0.76\end{array}$ & $\begin{array}{r}177 \pm 17 / 0.69 \\
-178 \pm 13 / 0.71\end{array}$ & $\begin{array}{r}169 \pm 18 / 0.65 \\
-164 \pm 11 / 0.79\end{array}$ \\
\hline Fe acc. / Carb. acc. & $\begin{array}{l}\text { GC14 } \\
\text { GC51 } \\
\text { PC72 }\end{array}$ & $\begin{array}{l}122 \\
119\end{array}$ & $\begin{array}{l} \pm 17 / 0.72 \\
\pm 21 / 0.50\end{array}$ & & \\
\hline Fe acc. $/ \mathrm{C}_{\text {org }}$ acc. & $\begin{array}{l}\text { GC14 } \\
\text { GC51 }\end{array}$ & & & & \\
\hline Fe acc. / Opal acc. & $\begin{array}{l}\text { GC14 } \\
\text { GC51 }\end{array}$ & 192 & $\pm 25 / 0.54$ & & \\
\hline Fe acc. / Ti acc. & $\begin{array}{l}\text { GC14 } \\
\text { PC72 }\end{array}$ & $\begin{array}{l}5 \\
1\end{array}$ & $\begin{array}{l} \pm 4 / 0.98 \\
\pm 2 / 0.99\end{array}$ & $\begin{array}{r}17 \pm 7 / 0.95 \\
1 \pm 2 / 0.99\end{array}$ & $\begin{aligned} 21 & \pm 11 / 0.86 \\
5 & \pm 3 / 0.98\end{aligned}$ \\
\hline $\mathrm{Fe} / \mathrm{Ti} / \delta^{18} \mathrm{O}$ & $\begin{array}{l}\text { GC14 } \\
\text { GC51 } \\
\text { PC72 }\end{array}$ & 116 & $\pm 13 / 0.84$ & & $40 \pm 19 / 0.64$ \\
\hline
\end{tabular}

\begin{abstract}
Cross-spectral analysis based on the Blackman-Tukey method [Jenkins and Watts, 1968]. Positive phase angles indicate the first variable leads the second. No phase angle is given if records are not coherent at the $80 \%$ confidence level, or if one variable shows no increase in variance at the period of interest. Values of coherency ${ }^{2}$ at $80 \%$ confidence are as follows: Core GC14 = $0.52 ; \mathrm{GC51}=0.42 ; \mathrm{PC72}=0.29$, with respective bandwidths of $0.0133,0.0095$, and 0.0095 and lags of 25,35 , and 35 . All records interpolated at $\Delta t=2 \mathrm{kyr}$ with cross-spectral analysis performed at $\Delta t=4 \mathrm{kyr}$. For Core GC51, only the $0-412 \mathrm{ky}$ was analyzed (the portion of the core for which ages are isotopically defined; see text); PC72 was analyzed from $0-600 \mathrm{kyr}$. Note that GC14 records only $240 \mathrm{kyr}$ of deposition and thus the $100 \mathrm{kyr}$ period is defined only by two cycles. Ti accumulation not included for GC51 due to many values being below XRF detection limit (Table A1).
\end{abstract}

of relationship between eolian input and biogenic accumulation. In RC11-210, eolian accumulation exhibits both interglacial and glacial maxima and does not correspond to the accumulation of any biogenic component. Similarly, in the shorter record at DSDP 503B, eolian accumulation does not correspond to either $\mathrm{CaCO}_{3}$ accumulation maxima or minima.

In addition to addressing the Fe fertilization hypothesis, these collected chemical and mineralogic data further document that the equatorial Pacific does not exhibit the same "glacially dusty" patterns found in Antarctic ice [Petit et al., 1990] and northwest Pacific sediment [Hovan et al., 1991]. This discrepancy emphasizes the importance of the temporal and spatial patchiness of terrigenous input to the surface and near-surface ocean. Indeed, as noted by Boyle [1983] in a study of a core located in the far eastern equatorial Pacific, the collected data sets indicate that such inputs not only respond to global aridity and wind strength, but to other factors as well.

\section{Solubllity Variation of the Terrigenous Component?}

The sedimentary Fe data cannot resolve differences in the soluble fraction of terrigenous input ( $10 \%$ of the total $\mathrm{Fe}$ input) [Duce and Tindale, 1991] through time and we therefore cannot explicitly rule out potential changes in Fe solubilization (and thus bioavailability of dissolved $\mathrm{Fe}$ ) that may result from variation in weathering or mineralogy of the terrigenous source over the glacial-interglacial timescale. Any hypothesis of Fe fertilization that requires temporal variation of $\mathrm{Fe}$ solubility, however, must invoke the solubility being unrelated to both $\mathrm{Fe}$ input and the total terrigenous input. Indeed, our data indicate that there is no increase in biogenic burial during those time periods where the terrigenous $\mathrm{Fe}$ input in fact increases by up to a factor of 5 (Figures 2 - 4). Thus if an Fe fertilized system were operating, the solubility of the terrigenous fraction would have to decrease during those periods of high particulate input. Recall, however, that neither the long-term decrease nor the higher frequency variations in $\mathrm{Fe} / \mathrm{Ti}$ in GC51, GC14, or PC72 correspond to glacial-interglacial cyclicity in biogenic burial, which implies that neither the $\mathrm{Fe}$ source terrain nor the solubility of the $\mathrm{Fe}$ component is varying in concert with biogenic production. This variation in $\mathrm{Fe} / \mathrm{Ti}$ is nonetheless intriguing; future studies of the terrigenous sediment fraction and potential source terrains should address this variation in order to constrain these observations.

\section{Terrigenous Input of Fe to the Equatorial Pacific}

The results of this study also address the input budget of $\mathrm{Fe}$ to equatorial Pacific waters. Modern estimates of the total average 


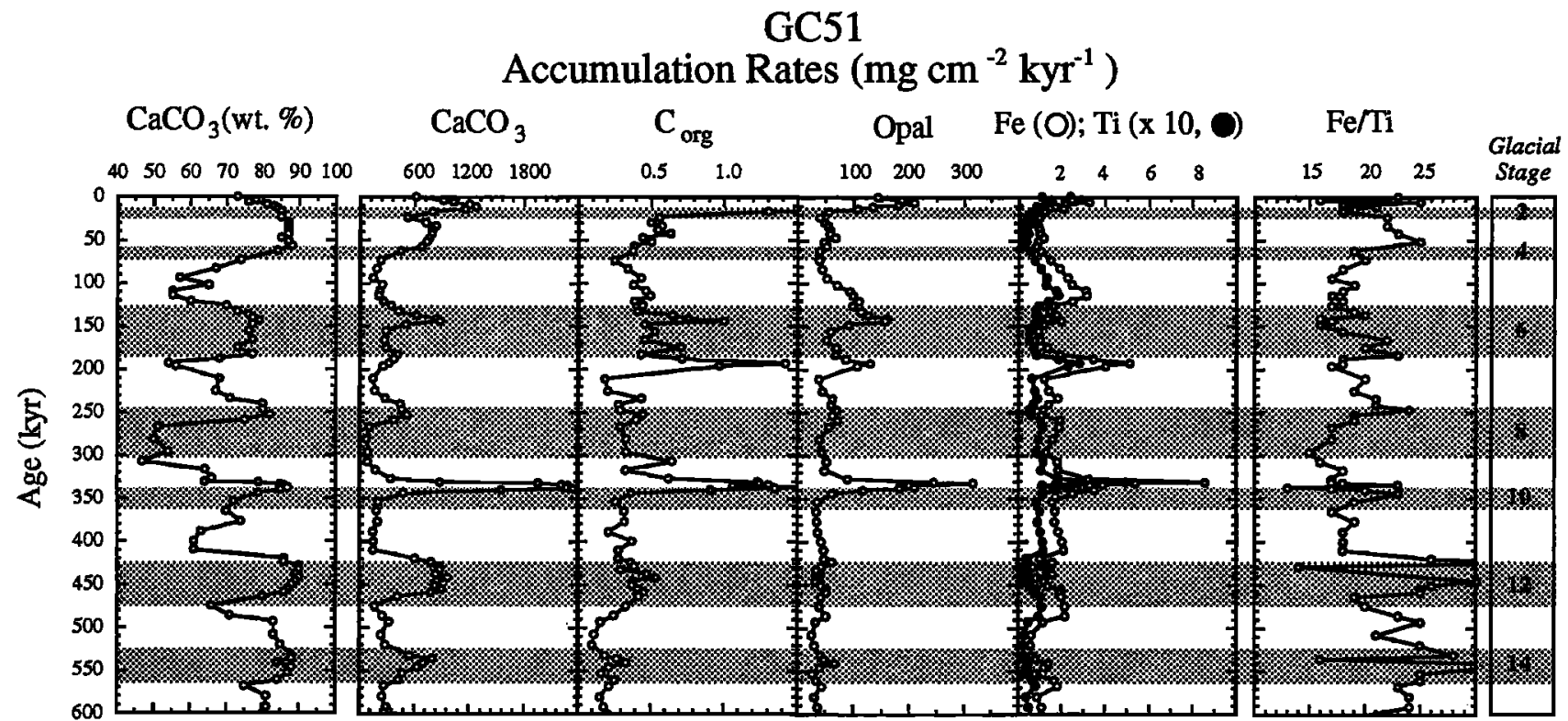

Figure 2. Downcore age profiles of the concentration of $\mathrm{CaCO}_{3}$ (wt. \%) in $\mathrm{GC51}$ (with numbered and shaded isotopic glacial stages from Imbrie et al. [1984]), the accumulation rates of $\mathrm{CaCO}_{3}, \mathrm{C}_{\mathrm{org}}$, opal, $\mathrm{Fe}$, and $\mathrm{Ti}$ ( $\left.\mathrm{x} 10\right)$, as well as the age profile of $\mathrm{Fe} / \mathrm{Ti}$. Missing values in $\mathrm{Ti}$ accumulation and $\mathrm{Fe} / \mathrm{Ti}$ reflect $\mathrm{Ti}$ concentrations below analytical detection limit (see text).

eolian flux of Fe to the ocean in the equatorial Pacific are on the order of $0.1 \mathrm{mg} \mathrm{cm}^{-2} \mathrm{kyr}^{-1}$ [Duce and Tindale, 1991]. This value is at least an order of magnitude smaller than that recorded in sediment over the longer timescale (Figures 2 - 4) as well as substantially smaller than values calculated from the eolian accumulation record at $\mathrm{RC} 11-210$ and $503 \mathrm{~B}$ (based on a representative $\mathrm{Fe}$ concentration in terrigenous matter [Taylor and McLennan, 1985] and the abundance of eolian matter in the cores [Rea et al., 1986; Chuey et al., 1987]). This data indicates that the importance of dust storms, which can deposit $\mathrm{Fe}$ at a rate on the order of $3 \mathrm{mg} \mathrm{cm}^{-2} \mathrm{kyr}^{-1}$ [Young et al., 1991], may be underestimated by modern observations and that the average eolian estimates may not be representative of the longer scale input. With the recent observation that the EUC is an additional and important source of particulate $\mathrm{Fe}$ to the region [Gordon et al., 1995], however, future research needs to quantify the amount of $\mathrm{Fe}$ from the EUC that is removed to the sediment (i.e., how much of the EUC Fe is indeed removed by particles settling

GC14

Accumulation Rates $\left(\mathrm{mg} \mathrm{cm}^{-2} \mathrm{kyr}^{-1}\right)$

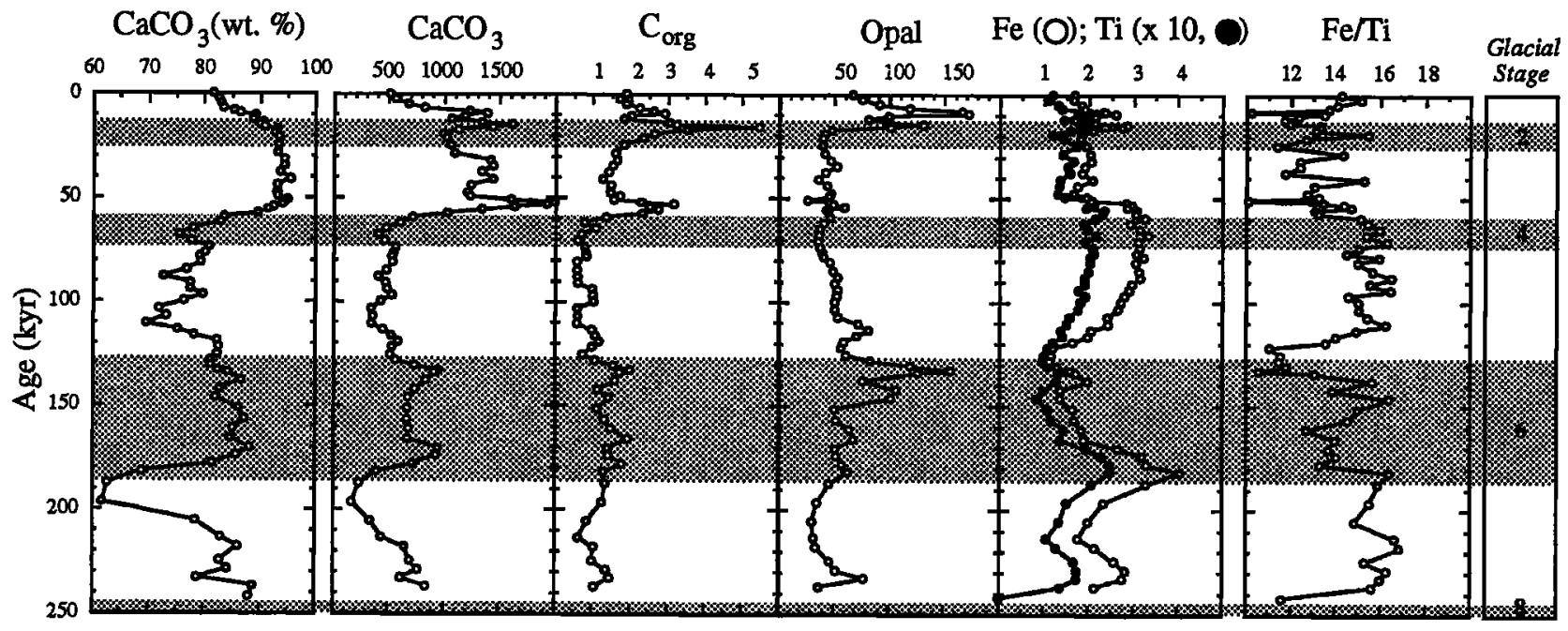

Figure 3. Downcore age profiles of the concentration of $\mathrm{CaCO}_{3}$ (wt. \%) in GC14 (with numbered and shaded isotopic glacial stages from Imbrie et al. [1984], note that glacial Stage 8 extends off the bottom of the figure), the accumulation rates of $\mathrm{CaCO}_{3}, \mathrm{C}_{\text {org }}$, opal, $\mathrm{Fe}$, and $\mathrm{Ti}(\mathrm{x} \mathrm{10}$ ), as well as the age profile of $\mathrm{Fe} / \mathrm{Ti}$. 


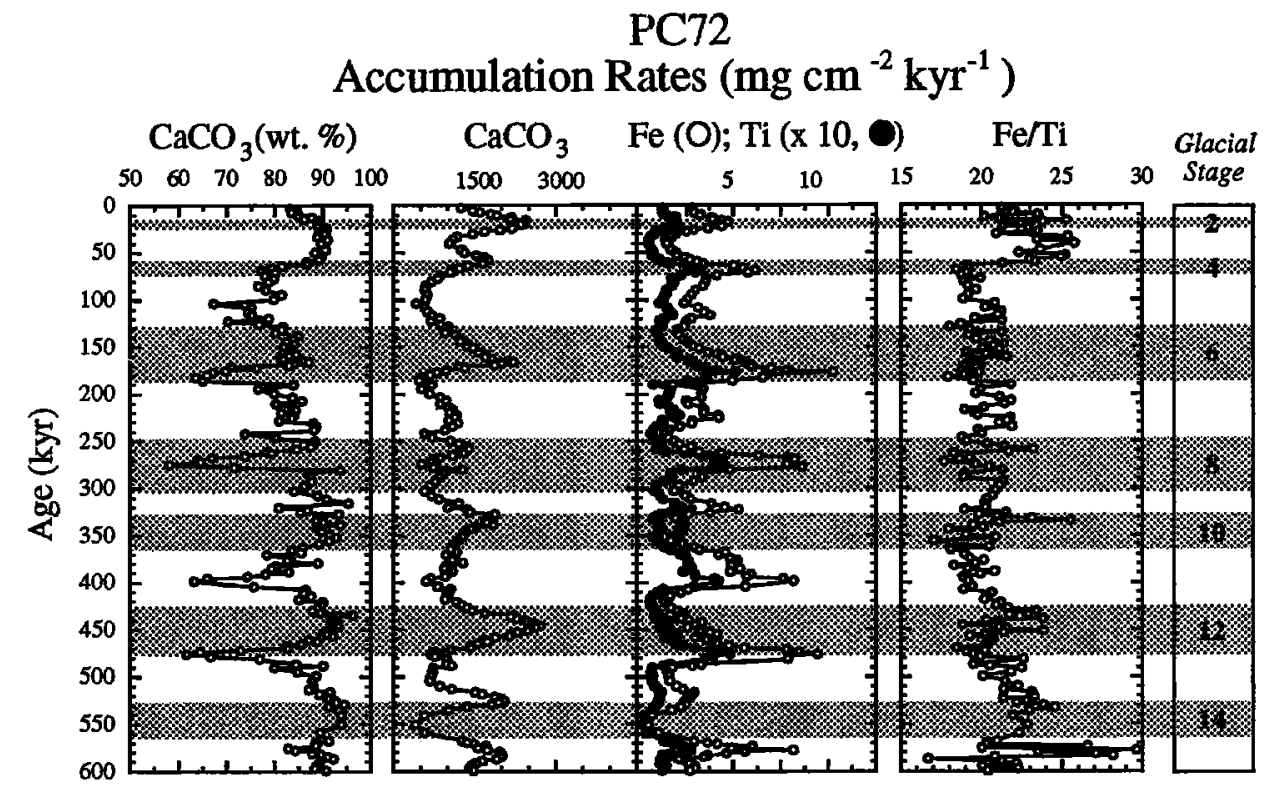

Figure 4. Downcore age profiles of the concentration of $\mathrm{CaCO}_{3}$ (wt. \%) in $\mathrm{PC}_{2}$ (with numbered and shaded isotopic glacial stages from Imbrie et al. [1984]), the accumulation rates of $\mathrm{CaCO}_{3}, \mathrm{C}_{\text {org }}$, opal, $\mathrm{Fe}$, and $\mathrm{Ti}(\mathrm{x} 10)$, as well as the age profile of $\mathrm{Fe} / \mathrm{Ti}$.

through the EUC). For example, previous studies of Fe and terrigenous deposition across the equatorial productivity gradient indicate that the flux of $\mathrm{Fe}$ and terrigenous material at $-4^{\circ} \mathrm{N}$ (located beneath the Intertropical Convergence Zone and intepreted as eolian in origin) is 3 to 5 times as large as the flux at the Equator [Murray and Leinen, 1993; Murray et al., 1993]. This is also consistent with the fact that eolian fluxes are known to be larger in the northern hemisphere [Duce and Tindale, 1991]. Thus several issues relating to the particulate Fe cycle in the Central equatorial Pacific remain unresolved.

\section{Conclusion}

Chemical and mineralogic data from the equatorial Pacific indicate that there is no relationship between terrigenous input of $\mathrm{Fe}$ and burial of carbon on the glacial-interglacial timescale. We reiterate the following points:

1. The accumulation of terrigenous material in general, and terrigenous $\mathrm{Fe}$ in specific, shows no consistent glacial or interglacial maxima or minima.

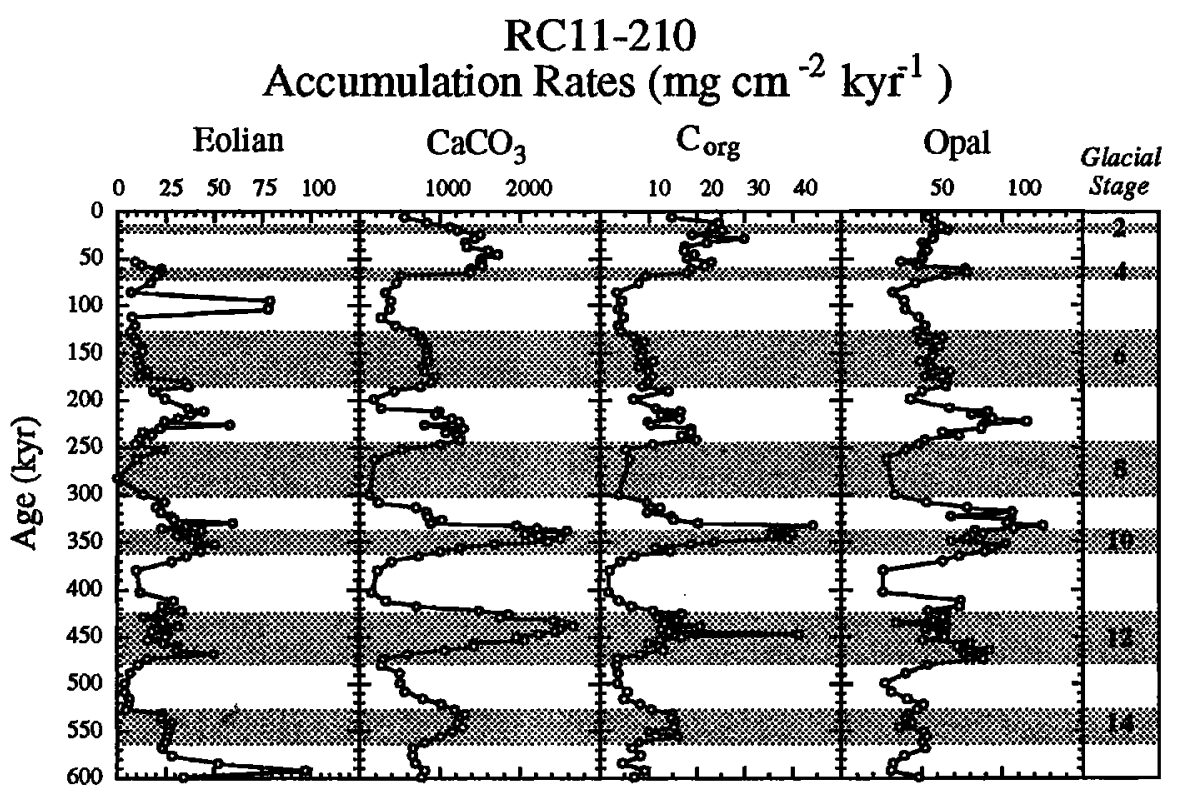

Figure 5. Downcore age profiles of the concentration of $\mathrm{CaCO}_{3}$ (wt. \%) in RC11-210 (with numbered and shaded isotopic glacial stages from Imbrie et al. [1984]), and of the accumulation rates of $\mathrm{CaCO}_{3}, \mathrm{C}_{\mathrm{org}}$, and opal. 
Table A1. Data for Core GC51

\begin{tabular}{|c|c|c|c|c|c|c|c|c|c|c|}
\hline \multirow[b]{2}{*}{$\begin{array}{c}\text { Depth, } \\
\text { cm }\end{array}$} & \multirow[b]{2}{*}{$\begin{array}{c}\text { Age, } \\
\text { kyr }\end{array}$} & \multicolumn{3}{|c|}{ weight \% } & \multicolumn{6}{|c|}{$\mathrm{mg} \mathrm{cm}^{-2} \mathrm{kyr}^{-1}$} \\
\hline & & $\mathbf{F e}$ & Opal & $\mathrm{C}_{\text {org }}$ & BAR & $\mathrm{CaCO}_{3}$ & Opal & $\mathrm{C}_{\text {org }}$ & $\mathbf{F e}$ & $\mathbf{T i}$ \\
\hline 0 & 0 & 0.28 & 16.9 & 0.47 & 845 & 615 & 143 & 3.97 & 2.25 & 0.106 \\
\hline 5 & 3.75 & 0.21 & 15.8 & 0.16 & 1168 & 915 & 185 & 1.87 & 1.84 & 0.154 \\
\hline 10 & 6.25 & 0.24 & 15.5 & 0.16 & 1348 & 1027 & 209 & 2.16 & 2.03 & 0.129 \\
\hline 15 & 8.75 & 0.15 & 12.2 & 0.11 & 1477 & 1200 & 180 & 1.62 & 1.37 & 0.124 \\
\hline 20 & 11.3 & 0.11 & 8.8 & 0.19 & 1528 & 1270 & 134 & 2.90 & 1.07 & 0.082 \\
\hline 25 & 13.8 & 0.15 & 7.7 & 0.23 & 1385 & 1157 & 107 & 3.19 & 1.29 & 0.108 \\
\hline 30 & 16.9 & 0.13 & 5.9 & 0.14 & 930 & 794 & 55 & 1.30 & 1.23 & 0.067 \\
\hline 35 & 23.6 & 0.15 & 6.4 & 0.09 & 618 & 524 & 39 & 0.56 & 1.48 & 0.045 \\
\hline 40 & 29.6 & 0.10 & 5.8 & 0.06 & 834 & 724 & 48 & 0.50 & 1.00 & \\
\hline 45 & 33.8 & 0.09 & 5.7 & 0.06 & 957 & 836 & 54 & 0.57 & 0.86 & 0.040 \\
\hline 50 & 38.3 & 0.11 & 6.4 & 0.06 & 910 & 792 & 58 & 0.55 & 1.02 & \\
\hline 55 & 42.8 & 0.11 & 6.3 & 0.07 & 906 & 786 & 57 & 0.63 & 1.11 & 0.043 \\
\hline 60 & 47.3 & 0.13 & 7.6 & 0.05 & 885 & 756 & 67 & 0.44 & 1.28 & \\
\hline 65 & 51.8 & 0.11 & 5.6 & 0.06 & 840 & 734 & 47 & 0.50 & 0.97 & 0.035 \\
\hline 70 & 57.1 & 0.11 & 6.7 & 0.05 & 772 & 677 & 52 & 0.39 & 1.04 & \\
\hline 75 & 62.5 & 0.19 & 7.3 & 0.07 & 537 & 450 & 39 & 0.38 & 1.80 & 0.055 \\
\hline 80 & 73.3 & 0.48 & 12.3 & 0.08 & 314 & 232 & 39 & 0.25 & 2.72 & 0.074 \\
\hline 85 & 83.1 & 0.67 & 15.5 & 0.12 & 283 & 191 & 44 & 0.34 & 2.93 & 0.103 \\
\hline 90 & 93.8 & 0.89 & 20.6 & 0.17 & 254 & 144 & 52 & 0.43 & 2.80 & 0.131 \\
\hline 95 & 102 & 0.65 & 18.5 & 0.10 & 381 & 248 & 70 & 0.38 & 2.28 & 0.128 \\
\hline 100 & 109 & 0.80 & 23.9 & 0.12 & 387 & 214 & 93 & 0.46 & 2.21 & 0.174 \\
\hline 105 & 114 & 0.83 & 25.8 & 0.13 & 380 & 208 & 98 & 0.49 & 2.20 & 0.185 \\
\hline 110 & 121 & 0.57 & 25.1 & 0.09 & 435 & 263 & 109 & 0.39 & 1.75 & 0.138 \\
\hline 115 & 126 & 0.33 & 19.7 & 0.09 & 496 & 346 & 98 & 0.45 & 1.41 & 0.095 \\
\hline 120 & 133 & 0.25 & 19.3 & 0.07 & 587 & 427 & 113 & 0.41 & 1.22 & 0.077 \\
\hline 125 & 137 & 0.22 & 15.5 & 0.08 & 813 & 620 & 126 & 0.65 & 1.30 & 0.088 \\
\hline 130 & 141 & 0.12 & 14.8 & 0.07 & 1085 & 839 & 160 & 0.76 & 0.74 & 0.085 \\
\hline 135 & 144 & 0.18 & 14.0 & 0.09 & 1112 & 880 & 155 & 1.00 & 1.08 & 0.120 \\
\hline 140 & 148 & 0.18 & 13.9 & 0.07 & 653 & 506 & 91 & 0.46 & 1.04 & 0.074 \\
\hline 145 & 156 & 0.24 & 15.7 & 0.14 & 377 & 288 & 59 & 0.53 & 1.37 & 0.050 \\
\hline 150 & 166 & 0.28 & 14.6 & 0.13 & 352 & 270 & 51 & 0.46 & 1.61 & 0.046 \\
\hline 155 & 175 & 0.34 & 17.5 & 0.18 & 393 & 287 & 69 & 0.71 & 1.99 & 0.068 \\
\hline 160 & 183 & 0.35 & 12.4 & 0.08 & 541 & 414 & 67 & 0.43 & 2.09 & 0.084 \\
\hline 165 & 188 & 0.63 & 15.7 & 0.13 & 549 & 374 & 86 & 0.71 & 2.44 & 0.188 \\
\hline 170 & 193 & 0.87 & 22.0 & 0.24 & 591 & 318 & 130 & 1.42 & 2.30 & 0.280 \\
\hline 175 & 196 & 0.87 & 22.9 & 0.21 & 463 & 257 & 106 & 0.97 & 2.93 & 0.230 \\
\hline 180 & 211 & 0.57 & 18.3 & 0.09 & 207 & 141 & 38 & 0.19 & 2.62 & 0.061 \\
\hline 185 & 225 & 0.54 & 17.7 & & 258 & 172 & 46 & 0.21 & 2.50 & 0.074 \\
\hline 190 & 234 & 0.46 & 15.8 & 0.11 & 398 & 283 & 63 & 0.44 & 2.35 & 0.088 \\
\hline 195 & 241 & 0.25 & 10.6 & & 564 & & 60 & 0.28 & 1.46 & 0.068 \\
\hline 200 & 247 & 0.20 & 12.1 & 0.05 & 581 & 466 & 70 & 0.29 & 1.19 & 0.049 \\
\hline 205 & 253 & 0.17 & 9.8 & & & & 63 & 0.45 & 0.75 & 0.057 \\
\hline 210 & 259 & 0.38 & 14.4 & 0.08 & 500 & 374 & 72 & 0.40 & 1.23 & 0.102 \\
\hline 215 & 267 & 0.91 & 26.9 & 0.14 & 207 & 106 & 56 & 0.29 & 1.70 & 0.111 \\
\hline 220 & 281 & 1.06 & 26.1 & 0.22 & 151 & 76 & 39 & 0.33 & 1.84 & 0.092 \\
\hline 225 & 296 & 0.73 & 25.1 & 0.19 & 175 & 94 & 44 & 0.33 & 1.31 & 0.083 \\
\hline 230 & 307 & 0.95 & 27.3 & 0.34 & 190 & 90 & 52 & 0.65 & 1.72 & 0.115 \\
\hline 235 & 317 & 0.68 & 17.9 & 0.12 & 272 & 174 & 49 & 0.33 & 1.74 & 0.104 \\
\hline 240 & 327 & 0.62 & 17.2 & 0.12 & 520 & 343 & 90 & 0.62 & 2.28 & 0.187 \\
\hline 245 & 331 & 0.62 & 17.8 & 0.09 & 1373 & 881 & 245 & 1.24 & 5.34 & 0.494 \\
\hline 250 & 332 & 0.22 & 12.7 & 0.05 & 2488 & 1961 & 317 & 1.24 & 2.48 & 0.298 \\
\hline 255 & 334 & 0.15 & 7.7 & 0.05 & & 2218 & 201 & 1.31 & 1.92 & 0.173 \\
\hline 260 & 335 & 0.12 & 6.9 & 0.04 & 2669 & 2290 & 183 & 1.07 & 1.65 & \\
\hline 265 & 337 & 0.11 & 7.9 & 0.06 & 2654 & 2268 & 209 & 1.59 & 1.85 & 0.223 \\
\hline 270 & 338 & 0.10 & 6.7 & 0.0 & 2705 & 2341 & 182 & 1.35 & 1.51 & 0.162 \\
\hline 275 & 340 & 0.19 & 6.5 & 0.05 & 1825 & 1556 & 118 & 0.91 & 2.69 & 0.175 \\
\hline 280 & 344 & 0.41 & 10.0 & 0.06 & 614 & 484 & 61 & 0.37 & 3.58 & 0.111 \\
\hline & & & 124 & & & & & 0.26 & 2.92 & $0 \times 84$ \\
\hline
\end{tabular}


Table A1. (continued)

\begin{tabular}{|c|c|c|c|c|c|c|c|c|c|c|}
\hline \multirow[b]{2}{*}{$\begin{array}{l}\text { Depth, } \\
\text { cm }\end{array}$} & \multirow[b]{2}{*}{$\begin{array}{c}\text { Age, } \\
\text { kyr }\end{array}$} & \multicolumn{3}{|c|}{ weight \% } & \multicolumn{6}{|c|}{$\mathrm{mg} \mathrm{cm}^{-2} \mathrm{kyr}^{-1}$} \\
\hline & & $\mathrm{Fe}$ & Opal & $C_{\text {org }}$ & BAR & $\mathrm{CaCO}_{3}$ & Opal & Corg & $\mathbf{F e}$ & $\mathbf{T i}$ \\
\hline 290 & 365 & 0.64 & 13.0 & 0.12 & 264 & 185 & 34 & 0.32 & 2.64 & 0.098 \\
\hline 295 & 377 & 0.62 & 13.0 & 0.12 & 267 & 198 & 35 & 0.32 & 2.40 & 0.088 \\
\hline 300 & 389 & 0.79 & 15.5 & 0.09 & 234 & 147 & 36 & 0.21 & 2.29 & 0.101 \\
\hline 305 & 400 & 0.81 & 17.2 & 0.15 & 248 & 151 & 43 & 0.37 & 2.16 & 0.110 \\
\hline 310 & 410 & 0.82 & 18.4 & 0.11 & 256 & 155 & 47 & 0.28 & 2.15 & 0.115 \\
\hline 315 & 420 & 0.14 & 6.9 & 0.04 & 704 & 606 & 48 & 0.28 & 1.01 & 0.038 \\
\hline 320 & 424 & 0.17 & 6.8 & 0.04 & 910 & 786 & 62 & 0.36 & 1.32 & 0.044 \\
\hline 325 & 429 & 0.07 & 4.3 & 0.04 & 974 & 879 & 42 & 0.39 & 0.65 & 0.047 \\
\hline 330 & 433 & 0.15 & 3.5 & 0.03 & 975 & 880 & 34 & 0.29 & 1.35 & \\
\hline 335 & 438 & 0.17 & 4.4 & 0.05 & 945 & 837 & 42 & 0.47 & 1.61 & \\
\hline 340 & 442 & 0.07 & 3.5 & 0.05 & 1077 & 968 & 38 & 0.54 & 0.77 & \\
\hline 345 & 446 & 0.12 & 3.3 & 0.04 & 952 & 846 & 32 & 0.38 & 1.15 & 0.040 \\
\hline 350 & 451 & 0.14 & 4.6 & 0.04 & 937 & 825 & 43 & 0.37 & 1.40 & 0.051 \\
\hline 355 & 455 & 0.19 & 4.9 & 0.04 & 1029 & 899 & 51 & 0.41 & 1.92 & 0.080 \\
\hline 360 & 459 & 0.21 & 5.6 & 0.05 & 906 & 780 & 51 & 0.45 & 1.87 & 0.076 \\
\hline 365 & 464 & 0.38 & 8.2 & 0.08 & 525 & 419 & 43 & 0.42 & 2.12 & 0.104 \\
\hline 370 & 475 & 0.84 & 15.4 & 0.13 & 256 & 169 & 39 & 0.33 & 2.94 & 0.109 \\
\hline 375 & 486 & 0.60 & 14.3 & 0.07 & 357 & 252 & 51 & 0.25 & 2.44 & 0.092 \\
\hline 380 & 493 & 0.29 & 8.4 & 0.04 & 393 & 324 & 33 & 0.16 & 1.09 & 0.045 \\
\hline 385 & 508 & 0.20 & 8.7 & 0.04 & 287 & 238 & 25 & 0.11 & 0.70 & 0.028 \\
\hline 390 & 520 & 0.17 & 9.0 & 0.03 & 339 & 288 & 31 & 0.10 & 0.59 & 0.022 \\
\hline 395 & 532 & 0.10 & 6.8 & 0.03 & 628 & 553 & 42 & 0.19 & 0.63 & 0.023 \\
\hline 400 & 536 & 0.09 & 5.3 & 0.03 & 901 & 796 & 48 & 0.27 & 0.67 & 0.049 \\
\hline 405 & 541 & 0.17 & 8.0 & 0.04 & 834 & 704 & 67 & 0.33 & 1.29 & 0.045 \\
\hline 410 & 546 & 0.17 & 5.6 & 0.03 & 718 & 633 & 40 & 0.22 & 1.15 & 0.039 \\
\hline 415 & 553 & 0.14 & 5.0 & 0.03 & 540 & 470 & 27 & 0.16 & 0.83 & 0.029 \\
\hline 420 & 561 & 0.33 & 6.7 & 0.05 & 509 & 425 & 34 & 0.25 & 1.77 & 0.067 \\
\hline 425 & 568 & 0.50 & 12.3 & 0.06 & 360 & 272 & 44 & 0.22 & 1.87 & 0.078 \\
\hline 430 & 580 & 0.28 & 9.8 & 0.05 & 310 & 252 & 30 & 0.16 & 1.03 & 0.037 \\
\hline 435 & 592 & 0.30 & 10.0 & 0.05 & 364 & 296 & 36 & 0.18 & 1.16 & 0.046 \\
\hline 440 & 601 & 0.30 & 10.6 & 0.06 & 400 & 316 & 42 & 0.24 & 1.15 & 0.060 \\
\hline 445 & 610 & 0.30 & 11.8 & 0.04 & 581 & 452 & 69 & 0.23 & 1.70 & 0.056 \\
\hline 450 & 615 & 0.20 & 9.7 & 0.07 & 868 & 732 & 84 & 0.61 & 1.50 & 0.047 \\
\hline 455 & 619 & 0.14 & 5.6 & 0.03 & 703 & 607 & 39 & 0.21 & 0.92 & \\
\hline
\end{tabular}

Data for $\mathrm{CaCO}_{3} \mathrm{wt}$ \% and Ti wt. \% are in Murray et al. [1993]. Ages from 0 to $412 \mathrm{kyr}$ from isotopic model in LaMontagne [1993]; from 412 to $619 \mathrm{kyr}$ from carbonate model in Murray et al. [1993]. BAR is bulk accumulation rate. Missing values in Ti accumulation are where Ti < detection limit.

Table A2. Data for Core GC14

\begin{tabular}{|c|c|c|c|c|c|c|c|c|c|c|c|c|}
\hline \multirow[b]{2}{*}{$\begin{array}{l}\text { Depth, } \\
\text { cm }\end{array}$} & \multirow[b]{2}{*}{$\begin{array}{l}\text { Age, } \\
\text { kyr }\end{array}$} & \multicolumn{5}{|c|}{ weight \% } & \multicolumn{6}{|c|}{$\mathrm{mg} \mathrm{cm}^{-2} \mathrm{kyr}^{-1}$} \\
\hline & & $\mathrm{CaCO}_{3}$ & Opal & $C_{\text {org }}$ & $\mathrm{Fe}$ & $\mathrm{Ti}$ & BAR & $\mathrm{CaCO}_{3}$ & Opal & $C_{\text {org }}$ & $\mathrm{Fe}$ & $\mathbf{T i}$ \\
\hline 0.5 & 0 & $\overline{82}$ & 10.8 & 0.30 & 0.27 & 0.019 & 618 & 504 & 66 & 1.88 & 1.67 & 0.12 \\
\hline 3.5 & 2.48 & 83 & 11.1 & 0.25 & 0.24 & 0.016 & 679 & 560 & 75 & 1.71 & 1.65 & 0.11 \\
\hline 6.5 & 4.81 & 83 & 11.1 & 0.23 & 0.23 & 0.016 & 813 & 674 & 91 & 1.88 & 1.83 & 0.13 \\
\hline 9.5 & 6.79 & 83 & 12.0 & 0.23 & 0.19 & 0.014 & 990 & 826 & 118 & 2.24 & 1.90 & 0.14 \\
\hline 12.5 & 8.17 & 85 & 11.5 & 0.18 & 0.16 & 0.016 & 1441 & 1228 & 166 & 2.62 & 2.36 & 0.23 \\
\hline 15.5 & 9.22 & 86 & 10.8 & 0.18 & 0.16 & 0.012 & 1601 & 1384 & 172 & 2.91 & 2.59 & 0.19 \\
\hline 18.5 & 10.40 & 89 & 7.5 & 0.15 & 0.16 & 0.013 & 1326 & 1182 & 99 & 2.02 & 2.13 & 0.17 \\
\hline 21.5 & 12.07 & 89 & 6.7 & 0.15 & 0.14 & 0.012 & 1203 & 1067 & 81 & 1.83 & 1.69 & 0.14 \\
\hline 24.5 & 13.59 & 91 & 6.8 & 0.21 & 0.14 & 0.012 & 1480 & 1340 & 100 & 3.03 & 2.13 & 0.18 \\
\hline 27.5 & 14.67 & 90 & 7.3 & 0.18 & 0.16 & 0.012 & 1791 & 1611 & 131 & 3.22 & 2.86 & 0.21 \\
\hline 30.5 & 15.74 & 91 & 6.4 & 0.35 & 0.17 & 0.013 & 1579 & 1434 & 101 & 5.45 & 2.73 & 0.21 \\
\hline 33.5 & 17.10 & 93 & 3.9 & 0.29 & 0.17 & 0.013 & 1213 & 1129 & 48 & 3.50 & 2.07 & 0.16 \\
\hline 36.5 & 18.97 & 93 & 3.8 & 0.25 & 0.17 & 0.011 & 1075 & 995 & 41 & 2.64 & 1.83 & 0.12 \\
\hline 39.5 & 20.90 & 93 & 3.6 & 0.21 & 0.16 & 0.013 & 1093 & 1020 & 40 & 2.34 & 1.80 & 0.14 \\
\hline
\end{tabular}


Table A2. (continued)

\begin{tabular}{|c|c|c|c|c|c|c|c|c|c|c|c|c|}
\hline \multirow[b]{2}{*}{$\begin{array}{l}\text { Depth. } \\
\text { cm }\end{array}$} & \multirow[b]{2}{*}{$\begin{array}{l}\text { Age, } \\
\text { kyr }\end{array}$} & \multicolumn{5}{|c|}{ weight $\%$} & \multicolumn{6}{|c|}{$\mathrm{mg} \mathrm{cm}{ }^{-2} \mathrm{kyr}^{-1}$} \\
\hline & & $\mathrm{CaCO}_{3}$ & Opal & Corg & $\mathrm{Fe}$ & $\mathbf{T i}$ & BAR & $\mathrm{CaCO}_{3}$ & Opal & Corg & $\mathbf{F e}$ & Ti \\
\hline 45.5 & 24.57 & 93 & 3.5 & 0.16 & 0.17 & 0.015 & 1132 & 1056 & 39 & 1.83 & 1.93 & 0.17 \\
\hline 51.5 & 28.41 & 93 & 3.5 & 0.14 & 0.17 & 0.012 & 1177 & 1096 & 41. & 1.59 & 2.02 & 0.14 \\
\hline 57.5 & 31.80 & 94 & 3.1 & 0.11 & 0.14 & 0.011 & 1501 & 1417 & 47 & 1.65 & 2.05 & 0.17 \\
\hline 63.5 & 34.46 & 94 & 3.5 & 0.10 & 0.12 & 0.010 & 1526 & 1441 & 53 & 1.54 & 1.90 & 0.15 \\
\hline 69.5 & 37.62 & 94 & 2.9 & 0.10 & 0.13 & 0.011 & 1431 & 1340 & 42 & 1.44 & 1.85 & 0.16 \\
\hline 75.5 & 40.81 & 95 & 2.4 & 0.08 & 0.14 & 0.009 & 1509 & 1440 & 36 & 1.27 & 2.08 & 0.14 \\
\hline 81.5 & 43.93 & 93 & 3.3 & 0.11 & 0.13 & 0.010 & 1330 & 1239 & 44 & 1.48 & 1.74 & 0.13 \\
\hline 87.5 & 47.49 & 93 & 3.6 & 0.11 & 0.13 & 0.010 & 1299 & 1208 & 47 & 1.47 & 1.66 & 0.13 \\
\hline 90.5 & 49.17 & 93 & 3.4 & 0.13 & 0.15 & 0.011 & 1327 & 1236 & 45 & 1.72 & 1.93 & 0.15 \\
\hline 93.5 & 50.84 & 95 & 1.5 & 0.09 & 0.12 & 0.012 & 1685 & 1600 & 26 & 1.55 & 2.05 & 0.20 \\
\hline 96.5 & 51.93 & 95 & 2.1 & 0.11 & 0.13 & 0.010 & 2108 & 1992 & 45 & 2.28 & 2.84 & 0.21 \\
\hline 99.5 & 52.99 & 94 & 2.4 & 0.15 & 0.14 & 0.010 & 2042 & 1919 & 49 & 3.15 & 2.93 & 0.20 \\
\hline 102.5 & 54.16 & 92 & 3.3 & 0.14 & 0.16 & 0.011 & 1761 & 1627 & 59 & 2.50 & 2.85 & 0.19 \\
\hline 105.5 & 55.57 & 91 & 2.9 & 0.19 & 0.21 & 0.016 & 1465 & 1338 & 43 & 2.74 & 3.07 & 0.23 \\
\hline 108.5 & 57.19 & 90 & 3.9 & 0.20 & 0.26 & 0.020 & 1151 & 1031 & 45 & 2.32 & 3.05 & 0.23 \\
\hline 111.5 & 59.27 & 84 & 5.4 & 0.16 & 0.38 & 0.025 & 860 & 719 & 47 & 1.36 & 3.26 & 0.21 \\
\hline 114.5 & 61.74 & 83 & 5.6 & 0.11 & 0.40 & 0.026 & 728 & 603 & 41 & 0.78 & 2.93 & 0.19 \\
\hline 117.5 & 64.55 & 78 & 6.1 & 0.18 & 0.51 & 0.032 & 612 & 477 & 37 & 1.08 & 3.13 & 0.20 \\
\hline 120.5 & 67.68 & 75 & 6.7 & 0.13 & 0.62 & 0.040 & 540 & 407 & 36 & 0.70 & 3.33 & 0.22 \\
\hline 123.5 & 70.71 & 78 & 6.0 & 0.10 & 0.52 & 0.032 & 595 & 462 & 35 & 0.60 & 3.10 & 0.19 \\
\hline 126.5 & 73.56 & 81 & 5.4 & 0.11 & 0.45 & 0.030 & 692 & 560 & 37 & 0.78 & 3.13 & 0.21 \\
\hline 129.5 & 76.27 & 80 & 5.8 & 0.12 & 0.45 & 0.031 & 680 & 545 & 39 & 0.82 & 3.06 & 0.21 \\
\hline 131.5 & 78.10 & 79 & 6.1 & 0.13 & 0.48 & 0.030 & 672 & 532 & 41 & 0.84 & 3.22 & 0.20 \\
\hline 134.5 & 80.86 & 79 & 6.8 & 0.09 & 0.45 & 0.030 & 675 & 535 & 46 & 0.58 & 3.04 & 0.20 \\
\hline 138.5 & 84.61 & 77 & 7.9 & 0.09 & 0.50 & 0.032 & 622 & 477 & 49 & 0.58 & 3.12 & 0.20 \\
\hline 141.5 & 87.80 & 73 & 9.5 & 0.11 & 0.56 & 0.034 & 560 & 407 & 53 & 0.59 & 3.14 & 0.19 \\
\hline 144.5 & 90.97 & 77 & 8.3 & 0.10 & 0.48 & 0.031 & 613 & 474 & 51 & 0.60 & 2.95 & 0.19 \\
\hline 147.5 & 93.85 & 77 & 8.5 & 0.16 & 0.46 & 0.028 & 628 & 486 & 53 & 0.98 & 2.89 & 0.18 \\
\hline 150.5 & 96.65 & 80 & 8.0 & 0.15 & 0.42 & 0.029 & 661 & 526 & 53 & 1.00 & 2.79 & 0.19 \\
\hline 153.5 & 99.67 & 76 & 8.9 & 0.18 & 0.48 & 0.032 & 564 & 430 & 50 & 1.02 & 2.71 & 0.18 \\
\hline 156.5 & 103.2 & 72 & 10.6 & 0.12 & 0.56 & 0.037 & 474 & 340 & 50 & 0.58 & 2.64 & 0.18 \\
\hline 159.5 & 106.9 & 73 & 11.0 & 0.13 & 0.49 & 0.032 & 490 & 359 & 54 & 0.61 & 2.42 & 0.16 \\
\hline 162.5 & 110.5 & 70 & 14.5 & 0.12 & 0.49 & 0.030 & 499 & 347 & 72 & 0.58 & 2.43 & 0.15 \\
\hline 165.5 & 113.5 & 75 & 13.6 & 0.17 & 0.34 & 0.023 & 596 & 448 & 81 & 0.99 & 2.05 & 0.14 \\
\hline 168.5 & 116.2 & 78 & 10.5 & 0.16 & 0.29 & 0.021 & 667 & 522 & 70 & 1.07 & 1.96 & 0.14 \\
\hline 171.5 & 118.9 & 82 & 8.3 & 0.17 & 0.23 & 0.017 & 708 & 583 & 59 & 1.18 & 1.63 & 0.12 \\
\hline 174.5 & 121.7 & 83 & 8.8 & 0.16 & 0.19 & 0.017 & 639 & 527 & 56 & 0.99 & 1.20 & 0.11 \\
\hline 177.5 & 125.2 & 82 & 9.8 & 0.12 & 0.19 & 0.016 & 622 & 513 & 61 & 0.74 & 1.15 & 0.10 \\
\hline 180.5 & 128.1 & 81 & 11.9 & 0.16 & 0.16 & 0.014 & 693 & 562 & 83 & 1.07 & 1.11 & 0.10 \\
\hline 183.5 & 130.5 & 81 & 13.0 & 0.17 & 0.14 & 0.012 & 912 & 740 & 119 & 1.56 & 1.29 & 0.11 \\
\hline 187.5 & 132.9 & 82 & 13.5 & 0.17 & 0.14 & 0.013 & 1155 & 952 & 156 & 1.99 & 1.59 & 0.15 \\
\hline 189.5 & 134.0 & 84 & 11.6 & 0.16 & 0.16 & 0.012 & 1090 & 917 & 126 & 1.72 & 1.71 & 0.13 \\
\hline 195.5 & 137.8 & 87 & 7.8 & 0.17 & 0.20 & 0.013 & 969 & 839 & 76 & 1.60 & 1.97 & 0.13 \\
\hline 201.5 & 142.1 & 83 & 11.9 & 0.13 & 0.15 & 0.011 & 894 & 740 & 106 & 1.14 & 1.37 & 0.10 \\
\hline 207.5 & 146.1 & 82 & 12.3 & 0.17 & 0.16 & 0.010 & 825 & 677 & 101 & 1.42 & 1.35 & 0.08 \\
\hline 213.5 & 151.2 & 86 & 6.5 & 0.15 & 0.21 & 0.014 & 779 & 671 & 50 & 1.14 & 1.64 & 0.11 \\
\hline 219.5 & 156.4 & 87 & 6.8 & 0.17 & 0.22 & 0.015 & 766 & 668 & 52 & 1.32 & 1.67 & 0.11 \\
\hline 225.5 & 161.0 & 85 & 7.9 & 0.18 & 0.23 & 0.018 & 802 & 683 & 64 & 1.48 & 1.83 & 0.14 \\
\hline 231.5 & 165.8 & 85 & 8.5 & 0.24 & 0.24 & 0.017 & 795 & 673 & 68 & 1.93 & 1.89 & 0.14 \\
\hline 237.5 & 170.3 & 88 & 4.8 & 0.13 & 0.25 & 0.018 & 1075 & 948 & 51 & 1.41 & 2.65 & 0.19 \\
\hline 243.5 & 173.8 & 86 & 4.8 & 0.13 & 0.30 & 0.021 & 1084 & 929 & 52 & 1.44 & 3.20 & 0.23 \\
\hline 249.5 & 177.9 & 81 & 6.5 & 0.20 & 0.37 & 0.028 & 883 & 720 & 57 & 1.79 & 3.29 & 0.25 \\
\hline 254.5 & 181.7 & 69 & 10.9 & 0.23 & 0.71 & 0.043 & 574 & 395 & 62 & 1.30 & 4.05 & 0.25 \\
\hline 261.5 & 187.5 & 63 & 12.3 & 0.36 & 0.89 & 0.056 & 368 & 231 & 45 & 1.34 & 3.28 & 0.21 \\
\hline 267.5 & 196.4 & 62 & 13.0 & 0.47 & 0.87 & 0.056 & 269 & 166 & 35 & 1.27 & 2.34 & 0.15 \\
\hline 273.5 & 205.3 & 78 & 7.0 & 0.20 & 0.46 & 0.031 & 431 & 338 & 30 & 0.86 & 1.99 & 0.13 \\
\hline 279.5 & 213.2 & 83 & 6.0 & 0.12 & 0.33 & 0.020 & 528 & 438 & 32 & 0.62 & 1.76 & 0.11 \\
\hline 283.5 & 217.9 & 86 & 4.5 & 0.14 & 0.29 & 0.017 & 747 & 643 & 34 & 1.04 & 2.14 & 0.13 \\
\hline 291.5 & 224.6 & 83 & 5.5 & 0.12 & 0.31 & 0.020 & 838 & 694 & 46 & 1.00 & 2.57 & 0.17 \\
\hline 297.5 & 228.8 & 84 & 5.7 & 0.15 & 0.31 & 0.019 & 911 & 767 & 52 & 1.37 & 2.82 & 0.17 \\
\hline 303.5 & 232.7 & 79 & 9.9 & 0.19 & 0.35 & 0.022 & 781 & 614 & 77 & 1.46 & 2.75 & 0.17 \\
\hline 309.5 & 236.7 & 89 & 3.9 & 0.11 & 0.23 & 0.014 & 942 & 836 & 36 & 1.06 & 2.12 & 0.14 \\
\hline
\end{tabular}


Table A3. Data for Core PC72

\begin{tabular}{|c|c|c|c|c|c|c|c|c|}
\hline \multirow[b]{2}{*}{$\begin{array}{l}\text { Depth, } \\
\text { cm }\end{array}$} & \multirow[b]{2}{*}{$\begin{array}{l}\text { Age, } \\
\text { kyr }\end{array}$} & \multirow[b]{2}{*}{$\begin{array}{c}\text { BAR, } \\
\mathrm{mg} \mathrm{cm}^{-2} \text { kyr } \\
\text {-1 }\end{array}$} & \multirow[b]{2}{*}{$\begin{array}{c}\mathrm{CaCO}_{3} \\
\text { wt. } \%\end{array}$} & \multirow[b]{2}{*}{$\begin{array}{l}\text { Fe, } \\
\text { ppm }\end{array}$} & \multirow[b]{2}{*}{$\begin{array}{c}\text { Ti, } \\
\text { ppm }\end{array}$} & \multicolumn{3}{|c|}{$\mathrm{mg} \mathrm{cm}^{-2} \mathrm{kyr}^{-1}$} \\
\hline & & & & & & $\mathrm{CaCO}_{3}$ & $\mathrm{Fe}$ & $\mathrm{Ti}$ \\
\hline 15 & 2.74 & 1498 & 83.2 & 1514 & 71.2 & 1246 & 2.27 & 0.107 \\
\hline 20 & 5.11 & 1751 & 83.9 & 1313 & 59.6 & 1469 & 2.30 & 0.104 \\
\hline 25 & 7.20 & 1919 & 83.4 & 1212 & 55.2 & 1600 & 2.33 & 0.106 \\
\hline 30 & 9.13 & 2127 & 84.8 & 1247 & 53.1 & 1804 & 2.65 & 0.113 \\
\hline 35 & 10.92 & 2265 & 84.8 & 1144 & 54.0 & 1921 & 2.59 & 0.122 \\
\hline 40 & 12.61 & 2494 & 87.5 & 1241 & 61.5 & 2182 & 3.10 & 0.153 \\
\hline 45 & 14.23 & 2524 & 86.1 & 1247 & 59.1 & 2172 & 3.15 & 0.149 \\
\hline 50 & 15.80 & 2734 & 89.3 & 1284 & 50.8 & 2442 & 3.51 & 0.139 \\
\hline 55 & 17.35 & 2739 & 89.0 & 1380 & 58.0 & 2439 & 3.78 & 0.159 \\
\hline 60 & 18.90 & 2722 & 89.2 & 1222 & 56.9 & 2427 & 3.33 & 0.155 \\
\hline 65 & 20.48 & 2644 & 89.1 & 1268 & 56.6 & 2355 & 3.35 & 0.150 \\
\hline 70 & 22.12 & 2516 & 88.9 & 1403 & 65.8 & 2237 & 3.53 & 0.165 \\
\hline 75 & 23.85 & 2420 & 90.8 & 1219 & 53.2 & 2197 & 2.95 & 0.129 \\
\hline 80 & 25.74 & 2187 & 90.6 & 1066 & 47.4 & 1981 & 2.33 & 0.104 \\
\hline 85 & 27.86 & 1889 & 89.6 & 1074 & 45.7 & 1692 & 2.03 & 0.086 \\
\hline 90 & 30.32 & 1631 & 90.3 & 948 & 45.3 & 1473 & 1.55 & 0.074 \\
\hline 95 & 33.22 & 1337 & 88.8 & 1037 & 40.9 & 1187 & 1.39 & 0.055 \\
\hline 100 & 36.62 & 1221 & 91.0 & 970 & 41.3 & 1111 & 1.18 & 0.050 \\
\hline 105 & 40.30 & 1164 & 89.7 & 1067 & 41.4 & 1044 & 1.24 & 0.048 \\
\hline 115 & 47.19 & 1390 & 90.6 & 1008 & 42.6 & 1259 & 1.40 & 0.059 \\
\hline 120 & 50.15 & 1502 & 88.4 & 1050 & 47.0 & 1328 & 1.58 & 0.071 \\
\hline 125 & 52.79 & 1722 & 89.8 & 948 & 37.6 & 1546 & 1.63 & 0.065 \\
\hline 130 & 55.16 & 1880 & 89.7 & 1025 & 41.1 & 1685 & 1.93 & 0.077 \\
\hline 135 & 57.37 & 1973 & 89.3 & 1095 & 47.6 & 1761 & 2.16 & 0.094 \\
\hline 140 & 59.49 & 1929 & 86.7 & 1282 & 54.9 & 1672 & 2.47 & 0.106 \\
\hline 145 & 61.60 & 1924 & 86.8 & 1435 & 67.3 & 1669 & 2.76 & 0.130 \\
\hline 150 & 63.74 & 1704 & 81.5 & 2358 & 123.0 & 1389 & 4.02 & 0.210 \\
\hline 155 & 66.05 & 1555 & 79.5 & 2832 & 147.2 & 1236 & 4.41 & 0.229 \\
\hline 160 & 68.36 & 1385 & 77.3 & 3557 & 192.6 & 1070 & 4.93 & 0.267 \\
\hline 165 & 70.96 & 1315 & 80.1 & 3508 & 184.1 & 1053 & 4.61 & 0.242 \\
\hline 170 & 73.88 & 1124 & 77.9 & 2975 & 158.4 & 876 & 3.34 & 0.178 \\
\hline 175 & 77.18 & 1030 & 79.8 & 2794 & 140.0 & 822 & 2.88 & 0.144 \\
\hline 180 & 80.89 & 899 & 78.7 & 3173 & 167.5 & 707 & 2.85 & 0.150 \\
\hline 185 & 85.03 & 783 & 76.6 & 3481 & 181.6 & 599 & 2.73 & 0.142 \\
\hline 190 & 89.54 & 750 & 78.2 & 3217 & 163.7 & 586 & 2.41 & 0.123 \\
\hline 195 & 94.30 & 767 & 81.4 & 2916 & 151.9 & 624 & 2.24 & 0.116 \\
\hline 200 & 99.15 & 746 & 79.8 & 2748 & 145.5 & 595 & 2.05 & 0.109 \\
\hline 205 & 103.88 & 623 & 67.3 & 3069 & 147.5 & 419 & 1.91 & 0.092 \\
\hline 210 & 108.32 & 779 & 75.1 & 3228 & 159.3 & 584 & 2.51 & 0.124 \\
\hline 215 & 112.37 & 850 & 74.5 & 3272 & 154.2 & 633 & 2.78 & 0.131 \\
\hline 220 & 116.04 & 953 & 75.3 & 3187 & 151.8 & 717 & 3.04 & 0.145 \\
\hline 225 & 119.37 & 1101 & 78.7 & 2026 & 103.4 & 866 & 2.23 & 0.114 \\
\hline 230 & 122.4 & 999 & 70.3 & 2035 & 95.6 & 702 & 2.03 & 0.095 \\
\hline 235 & 125.5 & 1147 & 76.7 & 1708 & 91.1 & 879 & 1.96 & 0.104 \\
\hline 240 & 128.4 & 1254 & 81.8 & 1530 & 84.8 & 1025 & 1.92 & 0.106 \\
\hline 245 & 131.4 & 1234 & 81.4 & 1361 & 70.6 & 1004 & 1.68 & 0.087 \\
\hline 250 & 134.4 & 1211 & 80.2 & 1372 & 64.5 & 971 & 1.66 & 0.078 \\
\hline 255 & 137.4 & 1360 & 85.0 & 1246 & 64.8 & 1156 & 1.69 & 0.088 \\
\hline 263 & 141.8 & 1456 & 83.9 & 1285 & 65.3 & 1221 & 1.87 & 0.095 \\
\hline 268 & 144.4 & 1508 & 84.1 & 1358 & 66.1 & 1243 & 2.05 & 0.100 \\
\hline
\end{tabular}


Table A3. (continued)

\begin{tabular}{|c|c|c|c|c|c|c|c|c|}
\hline \multirow[b]{2}{*}{$\begin{array}{l}\text { Depth, } \\
\text { cm }\end{array}$} & \multirow[b]{2}{*}{$\begin{array}{l}\text { Age, } \\
\text { kyr }\end{array}$} & \multirow[b]{2}{*}{$\begin{array}{c}\text { BAR, } \\
\mathrm{mg} \mathrm{cm}^{-2} \mathrm{kyr}^{-1}\end{array}$} & \multirow[b]{2}{*}{$\begin{array}{c}\mathrm{CaCO}_{3} \\
\text { wt } \%\end{array}$} & \multirow[b]{2}{*}{$\begin{array}{l}\text { Fe, } \\
\text { ppm }\end{array}$} & \multirow[b]{2}{*}{$\begin{array}{c}\text { Ti, } \\
\text { ppm }\end{array}$} & \multicolumn{3}{|c|}{$\mathrm{mg} \mathrm{cm}^{-2} \mathrm{kyr}^{-1}$} \\
\hline & & & & & & $\mathrm{CaCO}_{3}$ & $\mathrm{Fe}$ & $\mathrm{Ti}$ \\
\hline 273 & 146.8 & 1653 & 82.4 & 1336 & 62.3 & 1391 & 2.21 & 0.103 \\
\hline 278 & 149.1 & 1677 & 84.2 & 1372 & 66.1 & 1373 & 2.30 & 0.111 \\
\hline 283 & 151.3 & 1799 & 81.9 & 1433 & 71.3 & 1499 & 2.58 & 0.128 \\
\hline 288 & 153.4 & & 83.3 & 1596 & 75.6 & & & \\
\hline 293 & 155.4 & 1915 & 82.9 & 1548 & 81.2 & 1588 & 2.97 & 0.156 \\
\hline 298 & 157.4 & 2043 & 84.5 & 1625 & 80.0 & 1726 & 3.32 & 0.163 \\
\hline 303 & 159.3 & 2082 & 83.1 & 1699 & 79.9 & 1730 & 3.54 & 0.166 \\
\hline 308 & 161.0 & 2114 & 81.2 & 1692 & 78.5 & 1716 & 3.58 & 0.166 \\
\hline 313 & 162.7 & 2230 & 81.7 & 1877 & 96.9 & 1821 & 4.19 & 0.216 \\
\hline 318 & 164.4 & 2487 & 86.1 & 1629 & 83.5 & 2141 & 4.05 & 0.208 \\
\hline 323 & 166.0 & 2555 & 87.0 & 1755 & 88.6 & 2223 & 4.48 & 0.226 \\
\hline 328 & 167.6 & 2389 & 84.0 & 1916 & 97.4 & 2006 & 4.58 & 0.233 \\
\hline 333 & 169.2 & 2263 & 83.0 & 2096 & 105.1 & 1878 & 4.74 & 0.238 \\
\hline 338 & 171.0 & 1720 & 71.0 & 2762 & 146.3 & 1221 & 4.75 & 0.252 \\
\hline 343 & 172.8 & 1745 & 76.2 & 3198 & 162.3 & 1329 & 5.58 & 0.283 \\
\hline 348 & 174.9 & 1413 & 69.8 & 4399 & 234.2 & 986 & 6.22 & 0.331 \\
\hline 353 & 177.1 & 1206 & 67.0 & 6792 & 341.9 & 808 & 8.19 & 0.412 \\
\hline 358 & 179.6 & 1044 & 65.9 & 5194 & 274.4 & 688 & 5.42 & 0.286 \\
\hline 363 & 182.5 & 863 & 63.5 & 6077 & 338.9 & 548 & 5.24 & 0.292 \\
\hline 368 & 185.9 & 741 & 65.0 & 5349 & 274.2 & 481 & 3.96 & 0.203 \\
\hline 373 & 190.0 & 854 & 83.9 & 1725 & 79.0 & 716 & 1.47 & 0.067 \\
\hline 378 & 194.9 & 682 & 76.6 & 4013 & 200.8 & 522 & 2.74 & 0.137 \\
\hline 383 & 199.6 & 847 & 79.9 & 3119 & 158.7 & 677 & 2.64 & 0.134 \\
\hline 388 & 203.5 & 1040 & 83.8 & 2576 & 121.9 & 871 & 2.68 & 0.127 \\
\hline 393 & 207.1 & 1143 & 85.8 & 1755 & 80.4 & 980 & 2.01 & 0.092 \\
\hline 398 & 210.5 & 1084 & 80.3 & 1905 & 88.9 & 870 & 2.07 & 0.096 \\
\hline 403 & 213.8 & 1217 & 83.7 & 2217 & 110.0 & 1018 & 2.70 & 0.134 \\
\hline 406 & 216.9 & 1303 & 84.3 & 2131 & 112.4 & 1099 & 2.78 & 0.146 \\
\hline 413 & 219.8 & 1290 & 81.3 & 2125 & 108.6 & 1049 & 2.74 & 0.140 \\
\hline 418 & 222.6 & 1386 & 84.0 & 2416 & 122.3 & 1165 & 3.35 & 0.170 \\
\hline 423 & 225.4 & 1370 & 83.4 & 2488 & 114.1 & 1142 & 3.41 & 0.156 \\
\hline 429 & 228.2 & 1270 & 80.9 & 1781 & 82.5 & $102 \dot{8}$ & 2.26 & 0.105 \\
\hline 433 & 231.2 & 1353 & 88.0 & 1649 & 78.2 & 1190 & 2.23 & 0.106 \\
\hline 438 & 234.4 & 1240 & 88.6 & 1392 & 63.6 & 1099 & 1.73 & 0.079 \\
\hline 443 & 238.0 & 1091 & 88.2 & 1190 & 60.1 & 962 & 1.30 & 0.066 \\
\hline 448 & 242.1 & 771 & 73.8 & 1472 & 73.5 & 570 & 1.14 & 0.057 \\
\hline 453 & 246.2 & 893 & 80.3 & 1426 & 75.9 & 716 & 1.27 & 0.068 \\
\hline 458 & 250.1 & 1192 & 88.3 & 1272 & 66.7 & 1053 & 1.52 & 0.080 \\
\hline 463 & 253.3 & 1390 & 87.7 & 1240 & 61.0 & 1219 & 1.72 & 0.085 \\
\hline 468 & 255.9 & 1573 & 87.5 & 1406 & 65.6 & 1377 & 2.21 & 0.103 \\
\hline 473 & 258.5 & 1655 & 84.6 & 1152 & 49.6 & 1399 & 1.91 & 0.082 \\
\hline 478 & 260.8 & 1573 & 78.3 & 1628 & 75.1 & 1232 & 2.56 & 0.118 \\
\hline 483 & 263.0 & 1651 & 79.3 & 2125 & 116.2 & 1309 & 3.51 & 0.192 \\
\hline 488 & 265.2 & 1498 & 73.8 & 3387 & 178.4 & 1105 & 5.07 & 0.267 \\
\hline 493 & 267.3 & 1297 & 66.9 & 4811 & 249.7 & 868 & 6.24 & 0.324 \\
\hline 498 & 269.6 & 1178 & 64.0 & 5607 & 300.6 & 754 & 6.60 & 0.354 \\
\hline 503 & 272.0 & 1112 & 64.5 & 5670 & 320.0 & 718 & 6.31 & 0.356 \\
\hline 508 & 274.5 & 911 & 58.2 & 6878 & 350.2 & 530 & 6.27 & 0.319 \\
\hline 513 & 277.4 & 1041 & 71.6 & 6614 & 323.0 & 745 & 6.89 & 0.336 \\
\hline 518 & 280.5 & 1371 & 93.8 & 2822 & 132.3 & 1285 & 3.87 & 0.181 \\
\hline
\end{tabular}


Table A3. (continued)

\begin{tabular}{|c|c|c|c|c|c|c|c|c|}
\hline \multirow[b]{2}{*}{$\begin{array}{l}\text { Depth, } \\
\text { cm }\end{array}$} & \multirow[b]{2}{*}{$\begin{array}{l}\text { Age, } \\
\text { kyr }\end{array}$} & \multirow[b]{2}{*}{$\frac{\text { BAR, }}{\mathrm{mg} \mathrm{cm}^{-2} \mathrm{kyr}^{-1}}$} & \multirow[b]{2}{*}{$\begin{array}{c}\mathrm{CaCO}_{3} \\
\text { wt. } \%\end{array}$} & \multirow[b]{2}{*}{$\begin{array}{l}\text { Fe, } \\
\text { ppm }\end{array}$} & \multirow[b]{2}{*}{$\begin{array}{c}\text { Ti, } \\
\text { ppm }\end{array}$} & \multicolumn{3}{|c|}{$\mathrm{mg} \mathrm{cm}^{-2} \mathrm{kyr}^{-1}$} \\
\hline & & & & & & $\mathrm{CaCO}_{3}$ & $\mathrm{Fe}$ & $\mathbf{T i}$ \\
\hline 523 & 284.1 & 1082 & 86.9 & 2466 & 129.8 & 940 & 2.67 & 0.140 \\
\hline 528 & 288.1 & 979 & 87.4 & 2762 & 145.9 & 856 & 2.71 & 0.143 \\
\hline 533 & 292.5 & 895 & 87.8 & 2608 & 122.4 & 786 & 2.34 & 0.110 \\
\hline 538 & 297.4 & 788 & 86.2 & 2154 & 102.0 & 679 & 1.70 & 0.080 \\
\hline 543 & 302.7 & 701 & 84.2 & 2181 & 104.6 & 590 & 1.53 & 0.073 \\
\hline 548 & 308.2 & 807 & 89.1 & 2438 & 117.8 & 719 & 1.97 & 0.095 \\
\hline 551 & 311.2 & 934 & 90.8 & 2360 & 115.9 & 848 & 2.20 & 0.108 \\
\hline 558 & 315.6 & 1280 & 95.3 & 2421 & 119.9 & 1220 & 3.10 & 0.153 \\
\hline 564 & 320.0 & 1260 & 80.9 & 2884 & 142.4 & 1019 & 3.63 & 0.179 \\
\hline 568 & 322.7 & 1578 & 86.8 & 2674 & 141.1 & 1370 & 4.22 & 0.223 \\
\hline 574 & 325.2 & 1669 & 85.3 & 1806 & 83.9 & 1425 & 3.02 & 0.140 \\
\hline 578 & 327.5 & 2025 & 93.3 & 1034 & 52.1 & 1890 & 2.09 & 0.105 \\
\hline 584 & 329.7 & 1970 & 89.9 & 896 & 42.7 & 1771 & 1.77 & 0.084 \\
\hline 588 & 331.9 & 1974 & 89.4 & 796 & 34.4 & 1765 & 1.57 & 0.068 \\
\hline 594 & 334.1 & 1933 & 88.7 & 981 & 38.4 & 1714 & 1.90 & 0.074 \\
\hline 598 & 336.2 & 1938 & 90.3 & 985 & 46.7 & 1749 & 1.91 & 0.090 \\
\hline 604 & 338.5 & 1974 & 93.8 & 921 & 47.2 & 1850 & 1.82 & 0.093 \\
\hline 609 & 340.9 & 1719 & 89.1 & 1113 & 55.3 & 1531 & 1.91 & 0.095 \\
\hline 614 & 343.5 & 1610 & 89.4 & 1165 & 64.7 & 1439 & 1.88 & 0.104 \\
\hline 618 & 346.2 & 1502 & 89.8 & 1149 & 59.8 & 1349 & 1.73 & 0.090 \\
\hline 624 & 349.2 & 1433 & 91.4 & 1126 & 59.1 & 1310 & 1.61 & 0.085 \\
\hline 628 & 352.4 & 1391 & 92.8 & 1021 & 48.9 & 1291 & 1.42 & 0.068 \\
\hline 634 & 355.7 & 1328 & 91.3 & 1046 & 61.2 & 1213 & 1.39 & 0.081 \\
\hline 638 & 359.0 & 1301 & 89.3 & 1412 & 77.7 & 1161 & 1.84 & 0.101 \\
\hline 644 & 362.2 & 1277 & 85.9 & 1841 & 89.9 & 1097 & 2.35 & 0.115 \\
\hline 648 & 365.2 & 1283 & 83.7 & 2023 & 111.6 & 1074 & 2.60 & 0.143 \\
\hline 654 & 368.2 & 1377 & 85.5 & 2671 & 140.9 & 1178 & 3.68 & 0.194 \\
\hline 658 & 371.0 & 1245 & 78.5 & 2733 & 144.1 & 977 & 3.40 & 0.179 \\
\hline $\begin{array}{l}664 \\
668\end{array}$ & $\begin{array}{l}373.9 \\
376.7\end{array}$ & $\begin{array}{c}1365 \\
1332\end{array}$ & $\begin{array}{l}83.3 \\
82.6\end{array}$ & $\begin{array}{l}2837 \\
3118\end{array}$ & $\begin{array}{l}147.0 \\
154.7\end{array}$ & $\begin{array}{l}1137 \\
1100\end{array}$ & $\begin{array}{l}3.87 \\
4.15\end{array}$ & $\begin{array}{l}0.201 \\
0.206\end{array}$ \\
\hline 674 & 379.5 & 1459 & 89.0 & 2782 & 141.8 & 1299 & 4.06 & 0.207 \\
\hline 678 & 382.5 & 1224 & 80.3 & 3204 & 175.1 & 983 & 3.92 & 0.214 \\
\hline 684 & 385.5 & 1202 & 79.3 & 3563 & 185.8 & 953 & 4.28 & 0.223 \\
\hline 688 & 388.4 & 1322 & 83.0 & 2942 & 141.4 & 1097 & 3.89 & 0.187 \\
\hline 694 & 391.2 & 1287 & 78.2 & 3678 & 184.5 & 1006 & 4.73 & 0.237 \\
\hline 698 & 393.8 & 1293 & 74.3 & 3529 & 186.7 & 961 & 4.56 & 0.241 \\
\hline 702 & 395.9 & 1061 & 66.0 & 5733 & 302.8 & 700 & 6.09 & 0.321 \\
\hline 708 & 398.6 & 975 & 63.3 & 6710 & 349.3 & 616 & 6.54 & 0.340 \\
\hline 717 & 404.3 & 1086 & 75.7 & 4156 & 213.5 & 821 & 4.51 & 0.232 \\
\hline 722 & 407.5 & 1236 & 86.4 & 1673 & 88.5 & 1068 & 2.07 & 0.109 \\
\hline 727 & 410.9 & 1173 & 86.1 & 1513 & 73.3 & 1010 & 1.78 & 0.086 \\
\hline 732 & 414.4 & 1177 & 87.7 & 1151 & 56.6 & 1032 & 1.36 & 0.067 \\
\hline 737 & 417.9 & 1143 & 85.0 & 984 & 48.7 & 972 & 1.13 & 0.056 \\
\hline 742 & 421.2 & 1313 & 90.0 & 863 & 40.7 & 1181 & 1.13 & 0.053 \\
\hline 747 & 424.4 & 1426 & 89.7 & 907 & 43.4 & 1278 & 1.29 & 0.062 \\
\hline 752 & 427.3 & 1543 & 88.9 & 904 & 41.8 & 1372 & 1.40 & 0.064 \\
\hline 757 & 429.9 & 1670 & 87.8 & 989 & 42.3 & 1466 & 1.65 & 0.071 \\
\hline 762 & 432.2 & 1898 & 89.6 & 974 & 44.4 & 1701 & 1.85 & 0.084 \\
\hline 767 & 434.4 & 2311 & 96.3 & 828 & 38.1 & 2225 & 1.91 & 0.088 \\
\hline
\end{tabular}


Table A3. (continued)

\begin{tabular}{|c|c|c|c|c|c|c|c|c|}
\hline \multirow[b]{2}{*}{$\begin{array}{l}\text { Depth, } \\
\text { cm }\end{array}$} & \multirow[b]{2}{*}{$\begin{array}{l}\text { Age, } \\
\text { kyr }\end{array}$} & \multirow[b]{2}{*}{$\begin{array}{c}\text { BAR, } \\
\mathrm{mg} \mathrm{cm}^{-2} \mathrm{kyr}^{-1}\end{array}$} & \multirow[b]{2}{*}{$\begin{array}{c}\mathrm{CaCO}_{3}, \\
\text { wt. } \%\end{array}$} & \multirow[b]{2}{*}{$\begin{array}{l}\text { Fe, } \\
\text { ppm }\end{array}$} & \multirow[b]{2}{*}{$\begin{array}{c}\text { Ti, } \\
\text { ppm }\end{array}$} & \multicolumn{3}{|c|}{$\mathrm{mg} \mathrm{cm}^{-2} \mathrm{kyr}^{-1}$} \\
\hline & & & & & & $\mathrm{CaCO}_{3}$ & $\mathrm{Fe}$ & $\mathrm{Ti}$ \\
\hline 772 & 436.4 & 2354 & 93.0 & 716 & 32.0 & 2189 & 1.69 & 0.075 \\
\hline 777 & 438.3 & 2481 & 92.2 & 734 & 30.8 & 2286 & 1.82 & 0.076 \\
\hline 782 & 440.0 & 2632 & 92.5 & 799 & 39.4 & 2434 & 2.10 & 0.104 \\
\hline 787 & 441.7 & 2704 & 91.7 & 994 & 47.1 & 2479 & 2.69 & 0.127 \\
\hline 792 & 443.3 & 2796 & & & & 2570 & & \\
\hline 797 & 444.9 & 2850 & 92.0 & 838 & 44.5 & 2622 & 2.39 & 0.127 \\
\hline 802 & 446.4 & 2923 & 93.2 & 720 & 34.7 & 2723 & 2.11 & 0.102 \\
\hline 806 & 447.7 & 2853 & 92.0 & 719 & 34.1 & 2625 & 2.05 & 0.097 \\
\hline 812 & 449.6 & 2767 & 91.5 & 924 & 42.8 & 2532 & 2.56 & 0.118 \\
\hline 817 & 451.2 & 2701 & 91.9 & 970 & 40.6 & 2482 & 2.62 & 0.110 \\
\hline 822 & 452.9 & 2531 & 90.7 & 1196 & 56.0 & 2295 & 3.03 & 0.142 \\
\hline 827 & 454.6 & 2410 & 90.8 & 1374 & 67.9 & 2189 & 3.31 & 0.164 \\
\hline 832 & 456.5 & 2330 & 92.2 & 1051 & 54.4 & 2148 & 2.45 & 0.127 \\
\hline 837 & 458.5 & 2115 & 89.7 & 1116 & 53.9 & 1897 & 2.36 & 0.114 \\
\hline 842 & 460.6 & 1941 & 87.2 & 1484 & 71.9 & 1692 & 2.88 & 0.140 \\
\hline 847 & 462.7 & 1956 & 88.9 & 1683 & 82.1 & 1739 & 3.29 & 0.161 \\
\hline 852 & 464.9 & 1832 & 85.5 & 1820 & 89.6 & 1567 & 3.33 & 0.164 \\
\hline 857 & 467.0 & 1748 & 82.6 & 2181 & 108.0 & 1443 & 3.81 & 0.189 \\
\hline 862 & 469.2 & 1756 & 82.7 & 2536 & 137.3 & 1452 & 4.45 & 0.241 \\
\hline 867 & 471.4 & 1466 & 72.9 & 4256 & 210.5 & 1069 & 6.24 & 0.309 \\
\hline 872 & 473.6 & 1235 & 64.5 & 5467 & 286.3 & 797 & 6.75 & 0.354 \\
\hline 877 & 475.8 & 1131 & 61.7 & 6663 & 341.7 & 698 & 7.54 & 0.387 \\
\hline 882 & 478.2 & 1169 & 66.7 & 5426 & 272.0 & 779 & 6.34 & 0.318 \\
\hline 887 & 480.7 & 1299 & 76.9 & 4860 & 214.9 & 999 & 6.32 & 0.279 \\
\hline 892 & 486.6 & 1179 & 84.5 & 2232 & 114.3 & 996 & 2.63 & 0.135 \\
\hline 897 & 488.3 & 1203 & 90.1 & 1879 & 91.5 & 1084 & 2.26 & 0.110 \\
\hline 902 & 490.1 & 933 & 80.0 & 1547 & 68.8 & 746 & 1.44 & 0.064 \\
\hline 907 & 494.4 & 860 & 84.9 & 1477 & 67.7 & 730 & 1.27 & 0.058 \\
\hline 912 & 499.3 & 799 & 88.7 & 1645 & 81.8 & 708 & 1.31 & 0.065 \\
\hline 917 & 504.4 & 787 & 87.9 & 1724 & 80.2 & 691 & 1.36 & 0.063 \\
\hline 922 & 509.5 & 982 & 88.0 & 1629 & 73.2 & 864 & 1.60 & 0.072 \\
\hline 927 & 513.2 & 1256 & 87.2 & 1479 & 69.2 & 1094 & 1.86 & 0.087 \\
\hline 932 & 516.1 & 1668 & 91.5 & 1394 & 60.2 & 1526 & 2.33 & 0.100 \\
\hline 937 & 518.6 & 1854 & 89.3 & 1195 & 51.7 & 1657 & 2.22 & 0.096 \\
\hline 942 & 520.8 & 2080 & 90.8 & 1050 & 45.1 & 1889 & 2.18 & 0.094 \\
\hline 947 & 522.8 & 2183 & 91.3 & 937 & 43.9 & 1994 & 2.05 & 0.096 \\
\hline 952 & 524.9 & 2214 & 92.5 & 890 & 39.1 & 2048 & 1.97 & 0.087 \\
\hline 957 & 526.9 & 2108 & 92.8 & 905 & 40.8 & 1957 & 1.91 & 0.086 \\
\hline 962 & 529.2 & 1933 & 94.5 & 1025 & 43.0 & 1827 & 1.98 & 0.083 \\
\hline 967 & 531.8 & 1499 & 91.3 & 1193 & 48.6 & 1368 & 1.79 & 0.073 \\
\hline 972 & 535.3 & 1108 & 93.4 & 1292 & 56.2 & 1035 & 1.43 & 0.062 \\
\hline 977 & 540.7 & 622 & 93.8 & 1004 & 45.8 & 584 & 0.63 & 0.029 \\
\hline 982 & 550.5 & 436 & 93.9 & 1045 & 45.7 & 410 & 0.46 & 0.020 \\
\hline 987 & 559.0 & 664 & 89.5 & 1358 & 60.8 & 595 & 0.90 & 0.040 \\
\hline 992 & 567.8 & 1405 & 91.3 & 1656 & 79.1 & 1282 & 2.33 & 0.111 \\
\hline 997 & 569.5 & 1539 & 89.0 & 1892 & 92.3 & 1370 & 2.91 & 0.142 \\
\hline 1002 & 571.3 & 1707 & 88.6 & 1951 & 96.1 & 1506 & 3.33 & 0.164 \\
\hline 1008 & 573.4 & 1932 & 82.8 & 2481 & 93.4 & 1711 & 4.79 & 0.181 \\
\hline 1013 & 575.5 & 1907 & 82.8 & 2053 & 102.6 & 1579 & 3.92 & 0.196 \\
\hline 1018 & 577.4 & 2063 & 84.3 & 3156 & 106.4 & 1740 & 6.51 & 0.219 \\
\hline 1023 & 579.3 & 2251 & 88.0 & 1993 & 84.7 & 1981 & 4.48 & 0.191 \\
\hline
\end{tabular}




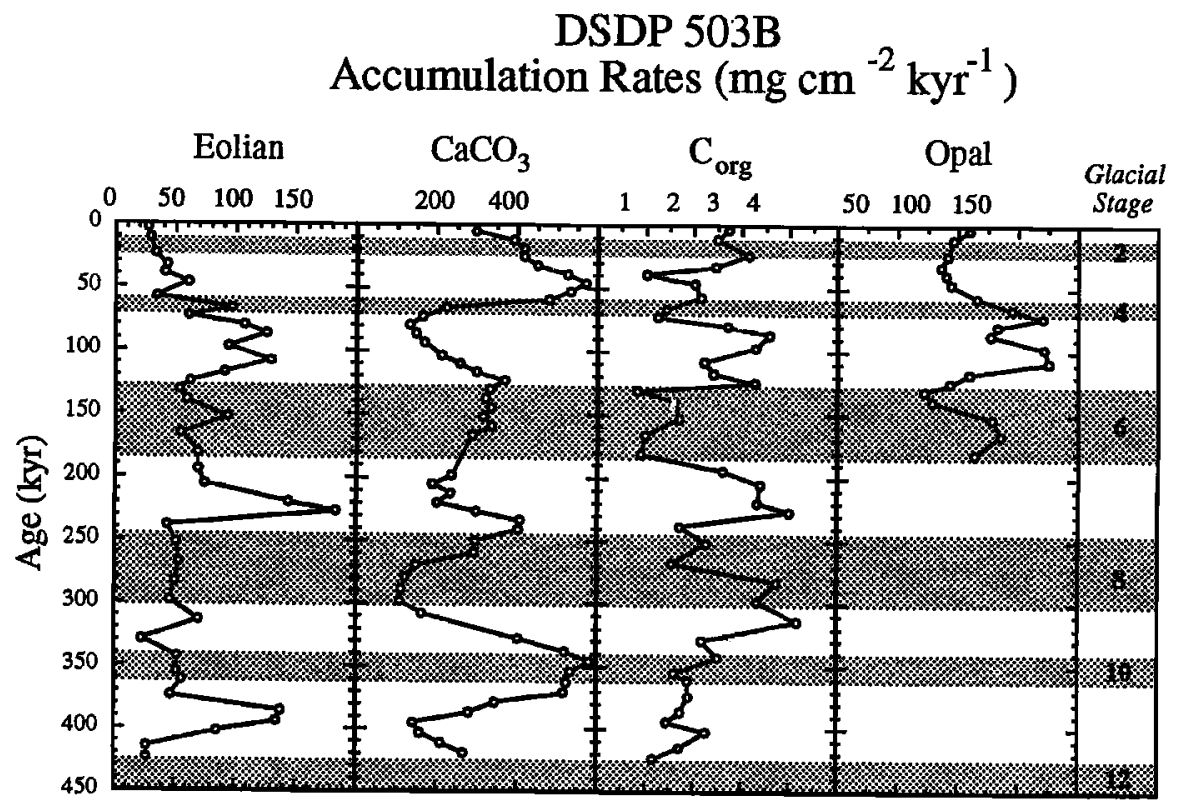

Figure 6. Downcore age profiles of the concentration of $\mathrm{CaCO}_{3}$ (wt. \%) in 503B (with numbered and shaded isotopic glacial stages from Imbrie et al. [1984]), and of the accumulation rates of $\mathrm{CaCO}_{3}, \mathrm{C}_{\text {org }}$, and opal.

2. The accumulation of the biogenic components $\mathrm{CaCO}_{3}$, $\mathrm{C}_{\text {org }}$, and opal show no linear $r^{2}$ or spectral relationship to that of terrigenous matter and $\mathrm{Fe}$.

3. The linear $r^{2}$ and spectral correlations between Fe or eolian input and $\mathrm{CaCO}_{3}$ concentration are either negative or zero and essentially $180^{\circ}$ out-of-phase.

4. Collectively, therefore, there is no evidence that the input of $\mathrm{Fe}$ influenced the final sedimentary sequestering of biogenically produced carbon in the equatorial Pacific.

Thus while much biological and chemical oceanographic research has indicated that $\mathrm{Fe}$ may indeed serve as a micronutrient in surface waters (as cited above), the sedimentary record indicates that the terrigenous input of $\mathrm{Fe}$ is not implicated in glacial/interglacial cycles in productivity and biogenic accumulation. These combined data sets, in concert with previously published records from elsewhere around the globe (e.g., from ice cores), indicate that input of Fe and bulk particulate matter to surface waters is patchy both spatially and temporally. Future work should address the spatial and temporal scales of the patchiness, further target the potential for solubility variations in terrigenous source terrain, and focus on the importance of factors other than wind strength and aridity to the bulk transport of terrigenous material.

\section{Appendix}

Data for Core GC51 (Table A1), Core GC14 (Table A2), and Core PC72 (Table A3).

Table A3. (continued)

\begin{tabular}{|c|c|c|c|c|c|c|c|c|}
\hline \multirow[b]{2}{*}{$\begin{array}{l}\text { Depth, } \\
\text { cm }\end{array}$} & \multirow[b]{2}{*}{$\begin{array}{l}\text { Age, } \\
\text { kyr }\end{array}$} & \multirow[b]{2}{*}{$\begin{array}{c}\text { BAR, } \\
m g \mathrm{~cm}^{-2} \mathrm{kyr}^{-1}\end{array}$} & \multirow[b]{2}{*}{$\begin{array}{c}\mathrm{CaCO}_{3} \\
\text { wt. } \%\end{array}$} & \multirow[b]{2}{*}{$\begin{array}{l}\mathrm{Fe}, \\
\mathrm{ppm}\end{array}$} & \multirow[b]{2}{*}{$\begin{array}{c}\text { Ti, } \\
\text { ppm }\end{array}$} & \multicolumn{3}{|c|}{$\mathrm{mg} \mathrm{cm}^{-2} \mathrm{kyr}^{-1}$} \\
\hline & & & & & & $\mathrm{CaCO}_{3}$ & $\mathrm{Fe}$ & $\mathbf{T i}$ \\
\hline 1028 & 581.1 & 2234 & 87.8 & 1659 & 61.2 & 1962 & 3.71 & 0.137 \\
\hline 1033 & 583.0 & 2238 & 89.7 & 1304 & 46.3 & 2006 & 2.92 & 0.104 \\
\hline 1038 & 585.0 & 2181 & 91.2 & 1254 & 60.2 & 1988 & 2.74 & 0.131 \\
\hline 1043 & 587.0 & 2080 & 92.3 & 817 & 48.9 & 1920 & 1.70 & 0.102 \\
\hline 1048 & 589.3 & 1846 & 89.6 & 1079 & 50.8 & 1654 & 1.99 & 0.094 \\
\hline 1053 & 591.7 & 1729 & 89.3 & 1225 & 55.3 & 1543 & 2.12 & 0.096 \\
\hline 1058 & 594.2 & 1649 & 88.8 & 1432 & 71.4 & 1464 & 2.36 & 0.118 \\
\hline 1063 & 596.8 & 1610 & 88.4 & 1478 & 66.4 & 1423 & 2.38 & 0.107 \\
\hline 1068 & 599.4 & 1650 & 90.8 & 1299 & 63.7 & 1497 & 2.14 & 0.105 \\
\hline
\end{tabular}

BAR is bulk accumulation rate 
Acknowledgments. Shipboard sample acquisition was funded by NSF grant OCE-8711221; shore based core curation, chemical analyses, and interpretation by NSF grants OCE-9022704, OCE-9022749, OCE9102410, and OCE-930109. We thank F. Crease for helping sample Core PC72, P. M. Murray and D. Rea for comments on an earlier version of the manuscript, and Phil Howell at Brown University for assistance with the spectral analyses. Two anonymous reviewers provided helpful suggestions and clarifications. This is U.S. JGOFS contribution 203.

\section{References}

Archer, D., Equatorial Pacific calcite preservation cycles: Production or dissolution?, Paleoceanography, 6, 561-571, 1991.

Arrhenius, G. O. S., Sediment cores from the east Pacific, Rep. Swed. Deep Sea Exped. 1947-1948, 5, 1-228, 1952.

Barber, R. T., and F. P. Chavez, Regulation of primary productivity rate in the equatorial Pacific, Limnol. Ocean., 36, 1803-1815, 1991.

Berger, W. H., Deep-sea carbonates: Pleistocene dissolution cycles, $J$. Foraminiferal Res., 3, 187-195, 1973.

Berger, W. H., Pacific carbonate cycles revisited: Arguments for and against productivity control, in Centenary of Japanese Micropaleontology, edited by K. Ishizaki and T. Saito, pp. 15-25, Terra Scientific, Tokyo, 1992.

Berger, W. H., and G. Wefer, Productivity of the glacial ocean: Discussion of the iron hypothesis, Limnol. Ocean., 36, 1899-1918, 1991.

Boyle, E. A., Chemical accumulation variations under the Peru Current during the past 130,000 years, J. Geophys. Res., 88, 7667-7680, 1983.

Bruland, K. W., J. R. Donat, and D. A. Hutchins, Interactive influences of bioactive trace metals on biological production in oceanic waters, Limnol. Ocean., 36, 1555-1577, 1991.

Chuey, J. M., D. K. Rea, and N. G. Pisias, Late Pleistocene paleoclimatology of the Central Equatorial Pacific: A quantitative record of eolian and carbonate deposition, Quat. Res., 28, 323-339, 1987.

Condie, K. C., Chemical composition and evolution of the upper continental crust: Contrasting results from surface samples and shales, Chem. Geol., 104, 1-37, 1993.

DiTullio, G. R., D. A. Hutchins, and K. W. Bruland, Interaction of iron and major nutrients controls phytoplankton growth and species composition in the tropical North Pacific Ocean, Limnol. Oceanogr., $38,495-508,1993$.

Duce, R. A., and N. W. Tindale, Atmospheric transport of iron and its deposition in the ocean, Limnol. Oceanogr., 36, 1715-1726, 1991.

Dymond, J., Geochemistry of Nazca plate surface sediments: An evaluation of hydrothermal, biogenic, detrital, and hydrogenous sources, in Nazca Plate: Crustal Formation and Andean Convergence, Geol. Soc. Am. Memoir, vol. 154, edited by L. D. Kulm, J. Dymond, E. J., Dasch, and D. M. Hussong, pp. 133-173, Geol. Soc. of Am., Boulder, Colo., 1981.

Dymond, J., E. Suess, and M. Lyle, Barium in deep-sea sediment: A geochemical proxy for paleoproductivity, Paleoceanography, 7, 163$181,1992$.

Emerson, S., Organic carbon preservation in marine sediments, in The Carbon Cycle and Atmospheric $\mathrm{CO}_{2}$ : Natural Variations Archean to Present, Geophys. Monogr. Ser., vol. 32, edited by E. T. Sundquist and W. S. Broecker, pp. 78-87, AGU, Washington, D. C., 1985.

Farrell, J. W., and W. L. Prell, Pacific $\mathrm{CaCO}_{3}$ preservation and $\delta^{18} \mathrm{O}$ since 4 Ma: Paleoceanic and paleoclimatic implications, Paleoceanography, 6, 485-498, 1991.

Frost, B. W., and N. C. Franzen, Grazing and iron limitation in the control of phytoplankton stock and nutrient concentration: a chemostat analogue of the Pacific equatorial upwelling zone, Mar. Ecol. Prog. Ser., 83, 291-303, 1992.

Gordon, R. M., K. H. Coale, and K. S. Johnson, Iron distributions in the equatorial Pacific: Implications for new production, Deep Sea Res, in press, 1995.

Herguera, J. C., and W. H. Berger, Paleoproductivity from benthic foraminifera abundance: Glacial to postglacial change in the westequatorial Pacific, Geology, 19, 1173-1176, 1991.
Herguera, J. C., and W. H. Berger, Glacial to postglacial drop in productivity in the western equatorial Pacific: Mixing rate vs. nutrient concentrations, Geology, 22, 629-632, 1994.

Hovan, S. A., D. K. Rea, and N. G. Pisias, Late Pleistocene continental climate and oceanic variability recorded in northwest Pacific sediments, Paleoceanography, 6, 349-370, 1991.

Imbrie, J., J. D. Hays, D. G. Martinson, A. McIntyre, A. C. Mix, J. J. Morley, N. G. Pisias, W. L. Prell, and N. J. Shackleton, The orbital theory of Pleistocene climate: Support from a revised chronology of the $\delta^{18} \mathrm{O}$ record, in Milankovitch and Clinuate, Part 1, edited by A. L. Berger et al., pp. 269-305, D. Reidel, Norwell, Mass., 1984.

Jenkins, G. M., and D. G. Watts, Spectral Analysis and Its Applications, 525 pp., Holden-Day, Oakland, Calif., 1968.

Kolber, Z. S., R. T. Barber, K. H. Coale, S. E. Fitzwater, R. M. Greene, K. S. Johnson, S. Lindley, and P. G. Falkowski, Iron limitation of phytoplankton photosynthesis in the equatorial Pacific Ocean, Nature, 371, 145-149, 1994.

LaMontagne, R. W., A 400 k.y. record of preservation of calcite, opal and organic carbon in the central equatorial Pacific: Implications for paleo- $\mathrm{CO}_{2}$ and late Pleistocene climate. MS thesis, Yale Univ., New Haven, Conn.. 1993.

Leinen, M., and D. Stakes, Metal accumulation rates in the central equatorial Pacific during Cenozoic time, Geol. Soc. Am. Bull., 90 , 357-375, 1979.

Lyle, M., D. W. Murray, B. P. Finney, J. Dymond, J. M. Robbins, and K. Brooksforce, The record of late Pleistocene biogenic sedimentation in the eastern tropical Pacific Ocean, Paleoceanography, 3, 39-59, 1988.

Lyle, M. W., F. G. Prahl, and M. A. Sparrow, Upwelling and productivity changes inferred from a temperature record in the central equatorial Pacific, Nature, 355, 812-815, 1992.

Martin, J. H., Glacial-interglacial $\mathrm{CO}_{2}$ change: the iron hypothesis, Paleoceanography 5, 1-13, 1990.

Martin, J. M., Iron as a limiting factor in oceanic productivity, in Primary Productivity and Biogeochemical Cycles in the Sea, edited by P. G. Falkowski and A. D. Woodhead, pp. 123-137, Plenum, New York, 1992.

Martin, J. H., S. E. Fitzwater, and R. M. Gordon, Iron deficiency limits phytoplankton growth in Antarctic waters, Global Biogeochem. Cycles, 4, 5-12, 1990.

Martin, J. H., R. M. Gordon, and S. E. Fitzwater, The case for iron, Limnol. Ocean., 36, 1793-1802, 1991.

Martin, J. H., et al., Testing the iron hypothesis in ecosystems of the equatorial Pacific Ocean, Nature, 371, 123-129, 1994.

Martin, W. R., M. Bender, M. Leinen, and J. Orchardo, Benthic organic carbon degradation and biogenic silica dissolution in the central equatorial Pacific, Deep-Sea Res., 38, 1481-1516, 1991.

Martinson, D., W. Menke, and P. Stoffa, An inverse approach to signal correlation, J. geophys. Res., 87, 4807-4818, 1982.

Morel, F. M. M., R. J. M. Hudson, and N. M. Price, Limitation of productivity by trace metals in the sea, Limnol. Ocean., 36, 1742$1755,1991$.

Murray, D. W., Spatial and temporal variations in sediment accumulation in the central tropical Pacific, Ph. D. dissertation, 343 pp., Oreg. State Univ., Corvallis, Oreg., 1987.

Murray, J. W., R. T. Barber, M. R. Roman, M. P. Bacon, and R. A. Feely, Physical and biological controls on carbon cycling in the equatorial Pacific, Science, 266, 58-65, 1994.

Murray, R. W., and M. Leinen, Chemical transport to the seafloor of the equatorial Pacific across a latitudinal transect at $135^{\circ} \mathrm{W}$; Tracking sedimentary major, trace, and rare earth element fluxes at the Equator and the TTCZ, Geochim. Cosmochim. Acta, 56, 4141-4163, 1993.

Murray, R. W., M. Leinen, and A. R. Isern, Biogenic flux of Al to sediment in the Central equatorial Pacific Ocean: Evidence for increased productivity during glacial episodes, Paleoceanography, 8 , 651-670, 1993.

Pedersen, T. F., Increased productivity in the eastern equatorial Pacific during the last glacial maximum (19,000 to $14,000 \mathrm{yr}$ B. P.), Geology, $11,16-19,1983$.

Pedersen, T. F., M. Pickering, J. S. Vogel, J. N. Southon, and D. E. Nelson, The response of benthic foraminifera to productivity cycles in the Eastern equatorial Pacific: Faunal and geochemical constraints on glacial bottom water oxygenation levels, Paleoceanography, 3, 157168, 1988. 
Pedersen, T. F., B. Nielsen, and M. Pickering, Timing of Late Quaternary productivity pulses in the Panama Basin and implications for atmospheric $\mathrm{CO}_{2}$, Paleoceanography, 6, 657-677, 1991.

Peng, T. -H., and ' $W$. S. Broecker, Factors limiting the reduction of atmospheric $\mathrm{CO}_{2}$ by iron fertilization, Limnol. Oceanogr., 36, 1919$1927,1991$.

Petit, J. R., L. Mounier, J. Jouzel, Y. S. Korotkevich, Y. I. Kotlayakov, and C. Lorius, Palaeoclimatological and chronological implications of the Vostok core dust record, Nature, 343, 56-58, 1990.

Pisias, N. G., and D. K. Rea, Late Pleistocene paleoclimatology of the Central equatorial Pacific: Sea surface response to the southeast trade winds, Paleoceanography, 3, 21-37, 1988.

Price, N., L. F. Andersen, and F. M. M. Morel, Iron and nitrogen nutrition of equatorial Pacific plankton, Deep Sea Res., 38, 1361-1378, 1991.

Rea, D. K., L. W. Chambers, J. M. Chuey, T. R. Janecek, M. Leinen, and N. G. Pisias, A 420,000 -year record of cyclicity in oceanic and atmospheric processes from the eastern equatorial Pacific, Paleoceanography, 1, 577-586, 1986.

Rea, D. K., N. G. Pisias, and T. Newberry, Late Pleistocene paleoclimatology of the Central equatorial Pacific: Flux patterns of biogenic sediments, Paleoceanography, 6, 227-244, 1991.

Sarmiento, J. L., and J. C. Orr, Three-dimensional simulations of the impact of Southern Ocean nutrient depletion on atmospheric $\mathrm{CO}_{2}$ and ocean chemistry, Linnol. Oceanogr: 36, 1928-1950, 1991.

Snoeckx, H., and D. K. Rea, Late Quaternary $\mathrm{CaCO}_{3}$ stratigraphy of the eastern equatorial Pacific, Paleoceanography, 9, 341-351, 1994.

Taylor, S. R., and S. M. McLennan, The Continental Crust: Its Composition and Evolution, 312 pp., Blackwell, Cambridge, Mass., 1985.
Watson, A. J., C. S. Law, K. A. Van Scoy, F. J. Millero, W. Yao, G. E. Friederich, M. I. Liddicoat, R. H. Wanninkhof, R. T. Barber, and K. $H$. Coale, Minimal effect of iron fertilization on sea-surface carbon dioxide concentrations, Nature, 371, 143-145, 1994.

Wei, K. -Y, Z. -W. Zhang, M. -T. Chen, A. R. Isern, C. -H Wang, and M Leinen, Late Quaternary paleoceanography of the Central Equatorial Pacific: A quantitative record of planktonic foraminiferal, isotopic, organic carbon and calcium carbonate changes, J. Geol. Soc. China, 37, 475-496, 1994.

Young, R. W., et al., Atmospheric iron inputs and primary productivity: Phytoplankton responses in the North Pacific, Global Biogeochem. Cycles, 5, 119-134, 1991.

C. W. Knowlton and M. Leinen, Graduate School of Oceanography, University of Rhode Island, Narragansett, RI 02882 . (email:cknowlto@gsosun1.gso.uri.edu; mleinen@gsosun1.gso.uri.edu)

A. C. Mix, College of Oceanic and Atmospheric Sciences, Oregon State University, Corvallis, OR 97331. (email: mix @oce.orst.edu)

D. W. Murray, Department of Geological Sciences, Brown University, Providence RI 02912. (email: dmurray @brown.edu)

R. W. Murray, Department of Earth Sciences, Boston University, Boston, MA 02215 (email: rmurray@bu.edu)

(Received April 13, 1995; revised September 12, 1995; accepted September 20, 1995) 